\title{
NOTAS SOBRE O APRISIONAMENTO NA BAHIA NO SÉCULO XIX ${ }^{1}$
}

\author{
Notes on imprisonment in Bahia in the $19^{\text {th }}$ century
}

\author{
Cláudia Moraes Trindade*
}

\begin{abstract}
RESUMO
O artigo é aborda a situação prisional da Bahia no XIX tendo como foco principal a Casa de Prisão com Trabalho, primeira penitenciária baiana. Nele contextualizo o surgimento da penitenciária e da pena privativa da liberdade no Brasil, especificamente na Bahia. Apresento o panorama do aprisionamento da província no contexto da reforma prisional baiana. Discuto a organização administrativa da penitenciária baiana, seus funcionários e atribuições. Analiso o trabalho nas oficinas, a situação da enfermaria, a escola de primeiras letras, o esquema de segurança, os presos, entre outros temas da instituição.
\end{abstract}

Palavras-Chave: Penitenciária, Casa de Prisão com Trabalho, Presos, Bahia-séc.XIX

\begin{abstract}
The article discusses the 19th century prison situation in Bahia, having as main focus the Labor Prison House, the first prison of Bahia. In the article I contextualize the emergence of the penitentiary and the prison sentence in Brazil, specifically in Bahia. I present the panorama of the manner of imprisonment in the province in the context of the Bahian prison reform. I discuss
\end{abstract}

\footnotetext{
1 Este artigo é um desdobramento do primeiro capítulo da minha tese de doutorado intitulada "Ser Preso na Bahia no século XIX", concluída em 2012 no PPGH/UFBA, sob a orientação do Professor Dr. João José Reis e coorientação da Professora Dra. Maria Cecília Velasco e Cruz. A pesquisa contou com o apoio do Conselho Nacional de Desenvolvimento Científico e Tecnológico - CNPq.

* Pesquisadora de Pós-Doutorado do Mestrado em História Regional e Local da Universidade do Estado da Bahia. E-mail para contato: claudiat@ufba.br
} 
the administrative organization of the Bahian penitentiary, its employees and assignments. I analyze the work in the workshops, the situation of the infirmary, the literacy training school, the security system, the prisoners, among other topics related to the institution.

Keywords: Prison, Labor Prison House, Prisoners, Bahia in the $19^{\text {th }}$ century

A prisão é muito antiga, mas não como lugar onde se cumpre uma sentença ou se busca reabilitar o criminoso para reinseri-lo na sociedade. Essa função, ela começou a ter, no Ocidente, com a reforma prisional a partir do final do século XVIII, nos contextos revolucionários da Europa e dos Estados Unidos. Para o historiador porto-riquenho Fernando Picó, o antes e o depois da reforma prisional diferencia o "estar preso e o ser preso". Segundo o autor, "até a segunda metade do século XVIII o preso não era parte constituinte da nossa sociedade". ${ }^{2}$ Antes disso, a pessoa ficava encarcerada até que fosse punida exemplarmente, executada ou açoitada, que quitasse sua "dívida" com a sociedade, o Estado, a religião ou outros indivíduos membros da comunidade. Somente após a reforma prisional, a prisão passou a existir da maneira como nós a concebemos atualmente. Começaria a era da penitenciária. Com a construção das penitenciárias, os presos foram afastados do olhar do público, antes acostumado a assistir aos castigos em praça pública como se fosse um espetáculo. Agora, o imaginário popular tornar-se-ia cada vez mais fértil para imaginar o que se passava por trás dos muros da prisão. $\mathrm{O}$ temor da punição não desapareceu exatamente, mas então a punição invisível é que era temida. ${ }^{3}$ Do outro lado do muro, o sentenciado passou a cumprir pena com a promessa de ser recuperado e, posteriormente, devolvido à sociedade como um novo homem, apto, sobretudo, a se enquadrar no mundo do trabalho. Não é por acaso que

2 Fernando Picó, El día menos pensado: Historia de los presidiarios em Puerto Rico (1793-1993), Local, Ediciones Huracán, 1994, p. 31.

3 Sobre o imaginário popular e o interesse pelas histórias de presos e prisões no início do século XX no Rio de Janeiro, ver Marcos Luiz Bretas, "What the Eyes Can’t See, pp. 101-122. Ver também Picó, El día menos pensado, p. 32. 
a reforma prisional coincide com a expansão vertiginosa do capitalismo.

Segundo Michel Foucault, a prisão teria nascido na França para atender exatamente aos interesses de uma sociedade capitalista industrial, que florescia após a queda do Antigo Regime que se seguiu à Revolução Francesa. Execuções, esquartejamentos, castigos físicos e demais humilhações que eram cometidas na praça pública contra os criminosos já vinham sendo combatidas pelos filósofos iluministas, que lançaram os fundamentos intelectuais de uma sensibilidade e de uma ideologia que fizeram aquelas formas de punição incompatíveis com os ideais liberais do Estado moderno. Foucault, no entanto, questiona se a classe burguesa em ascensão não teria reformado as leis penais visando tão somente proteger seus interesses, como por exemplo, promover corpos dóceis para o trabalho disciplinado requerido pela fábrica. Ele coloca em dúvida a justificativa humanitária utilizada frequentemente para explicar a substituição do suplício do corpo pela privação da liberdade. ${ }^{4}$

A discussão sobre as más condições dos cárceres nos Estados Unidos teve início ainda no período colonial, quando surgiram as primeiras associações protetoras com o objetivo de melhorar as cadeias. Em 1787, quatro anos após a guerra da independência, foi construída a Eastern State Penitentiary, primeira prisão com celas individuais, modelo que ficou conhecido como sistema da Pensilvânia. ${ }^{5}$ Nesse modelo penitenciário, o preso permanecia todo o tempo na cela, saindo apenas para um rápido banho de sol. O trabalho executado na própria cela era, por isso, artesanal. Era um modelo de alto custo devido às instalações individuais.

O sistema rival foi desenvolvido por volta de 1825, na penitenciária de Auburn, no estado de Nova York, e ficou conhecido como sistema de Auburn. Nele, todas as atividades diurnas dos presos eram coletivas e feitas no mais absoluto silêncio, e à noite eram isolados em celas individuais. No início, a quebra do silêncio era Vozes, 1987.

4 Michel Foucault, Vigiar e punir: história da violência nas prisões, $5^{\mathrm{a}}$ ed. Petrópolis,

5 Fernando Cadalso, Instituciones penitenciarias en los Estados Unidos, Madrid, Biblioteca Hispania, 1913, p. 102. Sobre a reforma prisional nos Estados Unidos, ver também Rothman, "Perfecting the Prison, pp. 100-116. 
punida com severos castigos corporais, que, logo depois, foram substituídos por períodos na solitária com regime alimentar controlado. ${ }^{6}$

Esses sistemas atraíram a atenção dos países que aderiram à reforma prisional e muitos deles trataram de enviar representantes para observar as experiências norte-americanas. Entre esses observadores estavam os franceses Alexis de Tocqueville e Gustave de Beaumont, o espanhol Fernando Cadalso, e latino-americanos como o peruano Mariano Felipe Paz Soldán, o chileno Francisco Solano Astaburuaga, o mexicano Mucio Valdovinos e o brasileiro Antonio José Miranda Falcão, primeiro diretor da Casa de Correção do Rio de Janeiro, entre outros. ${ }^{7}$ Muitos deles deixaram escritos que se tornaram valiosas fontes documentais sobre as impressões que tiveram dessas instituições. ${ }^{8}$

Do final do século XVIII até o início do século XX, países de todo mundo aderiram à reforma prisional e, gradativamente, as penitenciárias foram sendo implantadas de acordo com o contexto sócio histórico de cada um. Além da América Latina, a historiografia das prisões tem explorado a influência da Europa e dos Estados Unidos no nascimento da prisão em países da África e Ásia. Esses estudos têm também demonstrado a relação entre punição e raça, além de cronologias e tipos de encarceramento diferenciados dos países ocidentais.

6 Uma análise sobre esses sistemas pode ser vista em Foucault, Vigiar e punir, Parte iv, cap. 1. Outro estudo interessante e detalhado sobre o assunto é do espanhol Fernando Cadalso, Instituciones penitenciarias en los Estados Unidos, Madri, Espanha, Biblioteca Hispania, 1913, terceira parte, cap. 1. Dentre os estudos mais recentes, ver Rothman, "Perfecting the Prison: Unides States, 1789-1865". In: Norval Morris e David J. Rothman (orgs.). The Oxford History of the Prison (Nova York, Oxford University Press, 1995), pp. 100-116.

7 Carlos Aguirre, "Prison and Prisoners in Modernising Latin America (1800-1940)", in Frank Dikotter e Ian Brown (orgs.), Cultures of Confinement: A History of the Prison in Africa, Asia and Latin America (Ithaca, Nova York, Cornell University Press, 2007),p. 20; Sobre a visita de Miranda Falcão aos Estados Unidos, em 1854, ver Marilene Antunes Sant'Anna, “A imaginação do castigo: discursos e práticas sobre a Casa de Correção do Rio de Janeiro" (Tese de Doutorado em História, Universidade Federal do Rio de Janeiro, 2010). p. 56.

8 Dentre os mais conhecidos estão os escritos de Gustave de Beaumont e Alexis de Tocqueville, Du système pénitentiaire aux États-Unis et de son application en France, suivi d'un appendice sur les colonies pénales et de notes statistiques, Paris, Impr. de H. Fournier, 1833, 2e éd., Paris, C. Gosselin, 1836.

9 O termo "nascimento da prisão" é creditado a Michel Foucault, que primeiro o utilizou na década de 1970 em sua obra clássica Vigiar e punir. Sobre o Vietnam, ver Peter 
Os países da América Latina sofreram grande influência da reforma prisional na Europa e nos Estados Unidos. De um modo geral, o fato de a região ter inaugurado suas primeiras penitenciárias quase um século depois dos precursores pode ser atribuído a suas próprias particularidades sócio históricas. Sobre esse assunto, Mary Gibson sinaliza que "cada continente, cada ex-colônia ou cada nação moderna tem sua própria cronologia e o seu próprio modelo de punição". Por isso, ela sugere que não tenha emergido um modelo global definitivo de reforma prisional. ${ }^{10}$ Em quase todos os países da América Latina a reforma prisional esteve relacionada à construção de estados nacionais. Mesmo com um histórico comum de excolônias, os países latino-americanos tiveram particularidades políticas e sociais que influenciaram na periodização das suas reformas prisionais, bem como no funcionamento das prisões. A Casa de Correção da Corte, inaugurada em 1850 na província do Rio de Janeiro, foi a primeira penitenciária da América Latina. ${ }^{11}$ Em 1856,

Zinoman, The Colonial Bastille: A History of Imprisonment in Vietnam, 1862-1940, Berkeley, Los Angeles, University of California Press, 2001; Para o Japão, Daniel Botsman, Punishemnt and Power in the Making of Modern Japan, Princeton, N. J., 2005. Sobre as prisões da África colonial, ver Florence Bernault (org.), A History of Prison and Confinement in Africa, Portsmouth, N. H., 2003; Para a África subsaariana, ver David Williams, "The Role of Prisons in Tanzania: An Historical Perspective", Crime and Social Justice, $n^{\circ} 13$ (1980), pp. 27-37, entre outros. Sobre a Índia, ver Frank Dikotter, "The Promise of Repentance: The Prison in Modern China", in Dikotter e Brown (orgs.), Cultures of Confinement, pp. 269-303.

10 Mary Gibson, "Global Perspectives on the Birth of the Prison", The American Historical Review, vol. 116, n 4 (2011), p. 1057.

11 São Paulo inaugurou sua Casa de Correção em 1852, seguida de Pernambuco, em 1855, e da Bahia, em 1861. E assim, as penitenciárias foram sendo implantadas nas demais províncias brasileiras, umas construídas outras adaptadas nas antigas cadeias públicas, como foi o caso de Porto Alegre. Sobre a Casa de Correção da Corte, ver Carlos Eduardo Moreira de Araújo, "Cárceres imperiais: a Casa de Correção do Rio de Janeiro. Seus detentos e o sistema prisional do Império, 1830-1861" (Tese de Doutorado em História, Unicamp, 2009); e Sant'Anna, "A imaginação do castigo: discursos e práticas sobre a Casa de Correção do Rio de Janeiro"; sobre Pernambuco, ver Flávio de Sá Cavalcanti de Albuquerque Neto, “A reforma prisional no Recife oitocentista: da Cadeia à Casa de Detenção (1830-1874) (Dissertação de Mestrado em História, Universidade Federal de Pernambuco, 2008); sobre São Paulo, Salla, As prisões de São Paulo: 1822-1940, São Paulo, Anablume, 1999; e Flávia Maíra de Araújo Gonçalves, “Cadeia e Correção: sistema prisional e população carcerária na cidade de São Paulo, 1830-1890" (Dissertação de Mestrado em História, Universidade de São Paulo, 2010).; sobre Porto Alegre, Helena Marisa Vianna Paiva, "A Casa de Correção de Porto Alegre, 1889-1898" (Dissertação de Mestrado em História, Universidade Católica do Rio Grande do Sul, 2002); e Sandra Pesavento, Visões do cárcere, Porto Alegre, Editora Zouik, 2009. Sobre o Chile e Peru, ver Aguirre, "Prison and Prisoners in Modernising Latin America"; sobre Colombia e Cuba, ver Ricardo D. Salvatore e Carlos Aguirre, "The Birth of the Penitentiary in Latin America: Toward an Interpretive Social History of Prisons", 
foi a vez do Chile e do Peru. A penitenciária do Equador data de 1874, a da Argentina de 1877. A Colômbia, em 1934, e Cuba, em 1939, foram os últimos países a aderir à reforma prisional. ${ }^{12}$ Assim, foram bem diferentes os contextos dos países que implementaram a reforma prisional. ${ }^{13}$

No caso do Brasil, até mesmo nas províncias, houve especificidades quanto ao projeto, cronologia e funcionamento das penitenciárias. No período pós-Independência, a província da Bahia deu início a sua reforma prisional, que se estendeu ao longo do século XIX. O governo local, muitas vezes amparado por verbas e leis imperiais, adotou medidas gradativas que envolveram a criação de decretos provinciais, deslocamento das cadeias em direção às regiões periféricas da cidade, implantação de regulamentos que colocavam em prática a separação de presos segundo a natureza do crime, do gênero e da condição jurídica. ${ }^{14} \mathrm{Em}$ meio a essas medidas, a Câmara Municipal de Salvador, em 1832, iniciou a construção da primeira penitenciária da Bahia, inaugurada em 1861, que recebeu o nome de Casa de Prisão com Trabalho. ${ }^{15}$

in Ricardo Salvatore e Carlos Aguirre (orgs.), The Birth of the Penitentiary in Latin America: Essays on Criminology, Prison Reform, and Social Control, 1830-1940 (Austin, University of Texas Press, 1996), p. 9.

12 Aguirre, "Prison and Prisoners in Modernising Latin America". Sobre Colombia e Cuba, ver "The Birth of the Penitentiary in Latin America: Toward an Interpretive Social History of Prisons", in Ricardo Salvatore e Carlos Aguirre (orgs.), p. 9.

13 Nos países da África, por exemplo, as novas prisões foram construídas entre o final do século XIX e início do XX, no contexto do colonialismo europeu. Gibson, "Global Perspectives on the Birth of the Prison", p. 1041.

14 As medidas citadas estavam sempre ligadas ao processo político imperial e local. Por exemplo, as primeiras medidas para melhorar as cadeias e iniciar a construção da Casa de Prisão com Trabalho partiram da Câmara Municipal de Salvador por conta da Lei Municipal de 1828. A partir de 1834, o Ato Adicional determinou que a responsabilidade sobre as cadeias passasse a ser do governo provincial que, então, deu continuidade ao projeto iniciado pela municipalidade. A implantação dos regulamentos estava articulada com a reforma do Código de Processo Criminal, em 1841, que centralizou no Ministério da Justiça os assuntos da polícia, do judiciário e da Guarda Nacional. Tudo que dizia respeito a cadeias e penitenciárias ou Casas de Correção estava subordinado à esfera policial, inclusive a elaboração dos regulamentos. Sobre a reforma do Código do Processo, ver Marcos Luiz Bretas, Ordem na cidade: o exercício cotidiano da autoridade policial no Rio de Janeiro, 1907-1930, Rio de Janeiro, Rocco, 1997, pp. 41-43; ver também José Murilo de Carvalho, "A vida política", in José Murilo de Carvalho (org.), A construção nacional, 1830-1889, vol. 2 (Rio de Janeiro, Objetiva, 2012), pp. 83-129, entre outros.

15 Doravante CPCT. 
A nova instituição prisional baiana foi um símbolo de modernidade, um orgulho arquitetônico para os políticos e autoridades da época. Certa feita, poucos meses após a inauguração, os presos da CPCT escreveram numa petição coletiva que a instituição recém-inaugurada servia "como uma figa" - objeto de sorte - para os presidentes que governaram a província da Bahia durante os trinta anos de sua construção. Com isso os presos significavam o orgulho que os governantes tinham da penitenciária. ${ }^{16}$ A reforma prisional na Bahia, e no Brasil de um modo geral, deve ser pensada à luz de um contexto ideológico e mental em que modernidade e civilização significavam seguir os padrões europeus, mas, no caso específico da prisão, o modelo seria aquele dos sistemas penitenciários norte-americanos. A sociedade vivia a decadência do trabalho escravo, e suas elites planejavam estratégias para controlar e instrumentalizar para o trabalho a bem mais numerosa população livre. A reforma prisional no Brasil, além disso, fazia parte de um pacote civilizatório que incluía novas regras para o estabelecimento de cemitérios, asilos para alienados e mendigos, colégios, além de projetos de urbanização mais amplos. ${ }^{17}$

O Código Criminal do Império, de 1830, elaborado à luz das ideias liberais, inovou ao instaurar a pena de prisão com trabalho e prisão simples para a maioria dos delitos. ${ }^{18}$ No entanto, ao manter penas como desterro, degredo, morte, galés e optou pela permanência

16 João Byspo das Neves para o presidente da província, março de 1862, APEBa, Polícia, Casa de Prisão, maço 3082. Durante o processo de construção da CPCT, é possível observar nos relatórios e nas correspondências a expectativa que os presidentes de província aparentavam ter da futura prisão modelo da Bahia.

17 Para o caso baiano, ver João José Reis, A morte é uma festa: ritos fúnebres e revolta popular no Brasil do século XIX, São Paulo, Companhia das Letras, 1991; Vera Nathália dos Santos Silva, "Equilíbrio distante: a mulher, a medicina mental e o asilo. Bahia 1874-1912" (Dissertação de Mestrado, Universidade Federal da Bahia, 2005); Venétia Durando Braga Rios, "O Asylo de São João de Deus: as faces da loucura" (Tese de Doutorado, Pontifícia Universidade Católica de São Paulo, 2006); Walter Fraga Filho, Mendigos, moleques e vadios na Bahia do século XIX, Salvador, Edufba/ São Paulo, Hucitec, 1999; Maria das Graças Andrade Leal, "A arte de ter um ofício. O Liceu das Artes e Ofícios da Bahia - 1872/1977" (Dissertação de Mestrado, Universidade Federal da Bahia, 1996)"; Consuelo Novais Sampaio, 50 anos de urbanização: Salvador da Bahia no século XIX, Rio de Janeiro, Versal, 2005.

18 Sobre o liberalismo na França e sua difusão para outros países, ver René Rémond, O século XIX (1815-1914), São Paulo, Cultrix, 1981, pp. 25-48. Uma discussão sobre o processo de elaboração do Código Criminal do Império voltada para a temática da reforma prisional poder ser vista no trabalho de Albuquerque Neto, "A reforma prisional no Recife oitocentista", pp. 27-51. 
de práticas de punição vigentes na legislação portuguesa e aplicada no Brasil desde o início da colonização, no que, aliás, não diferia muito das penas vigentes na Europa na época. ${ }^{19}$ O Código Criminal previa a pena de açoites somente para os escravos, a de galés era aplicada só para homens livres ou escravos, mulheres não. A pena de morte poderia ser aplicada em homens e mulheres de condição livre ou escrava. No caso da mulher grávida, "não se executará a pena de morte, nem mesmo ela será julgada, em caso de o merecer, senão quarenta dias depois do parto". ${ }^{20}$ Os crimes de homicídio, latrocínio ou liderança de insurreição podiam levar o réu à pena de morte caso ele fosse enquadrado no grau máximo do respectivo artigo. O que definia o grau mínimo, médio ou máximo eram as circunstâncias agravantes ou não do crime. ${ }^{21}$

Para os escravos, o Código Criminal praticamente resumia, no seu Artigo 60, "Si o réu for escravo, e incorrer em pena que não seja a capital ou de galés, será condenado na de açoites, e, depois de sofrê-los, será entregue a seu senhor, que se obrigará a trazê-lo com um ferro, pelo tempo e maneira que o juiz designar". ${ }^{22}$ Durante o século XIX, a pena de açoite foi combatida por muitos juristas brasileiros, mas só foi extinta no ano de $1886 .{ }^{23}$ Essas penas coexistiram no Brasil com o aprisionamento moderno que se tentava

19 Originalmente, o Livro V das Ordenações Filipinas determinava que o condenado a galés fosse remetido às embarcações para remar. Com o tempo essa pena foi comutada para trabalhos forçados em obras públicas.

20 Araujo Filgueiras Junior, Código Criminal do Império do Brasil Anotado, Rio de Janeiro, Eduardo \& Henrique Laemmert, 1876, p.31.

21 Eis algumas dessas circunstâncias constantes no Artigo 16 do Código Criminal do Império: $§ 1$. Ter o delinquente cometido o crime de noite ou em lugar ermo; $\$ 2$.Ter o delinquente cometido o crime com veneno, incêndio ou inundação; $\$ 3$ Ter o delinquente reincidido em delito da mesma natureza; $\$ 4$.Ter sido o delinquente impelido por um motivo reprovado ou frívolo; $\$ 5$. Ter o delinquente faltado ao respeito devido à idade do ofendido, quando este for mais velho, tanto que possa ser seu pai, entre outros até completar o $17^{\circ}$ parágrafo, continuando no Artigo 17 com mais oito parágrafos. Filgueiras Junior, Código Criminal do Império do Brasil Anotado, pp.17-21.

22 Idem, p.48.

23 A Lei 3.310 , de 15 de outubro de 1886, no seu Artigo $1^{\circ}$ revoga o Artigo 60 do Código Criminal e a Lei n. 4, de 10 de junho de 1835, na parte em que impõem a pena de açoites. Sobre os debates dos juristas em torno da extinção dos açoites, ver Lenine Nequete, $\mathrm{O}$ escravo na jurisprudência brasileira: magistratura e ideologia no segundo reinado, Porto Alegre, Editora da Revista de Jurisprudência e outros impressos do Tribunal de Justiça, 1988, capitulo 2. 
implantar nas penitenciárias e com os discursos reformadores, tanto aos livres como aos escravos. ${ }^{24}$

Edmundo Coelho questiona a ideia de que um espírito reformista tenha tomado conta do Brasil independente em oposição ao sistema legal português. Observa o autor que o nosso Código Criminal "mantinha procedimentos bárbaros como, por exemplo, o ritual da pena de morte detalhado no artigo 40 e que não diferia muito daquele a que foi submetido Tiradentes pela legislação portuguesa". ${ }^{25}$ Mas Tiradentes e outros condenados à pena capital, como os rebeldes de 1798 na Bahia, foram também esquartejados, não esqueçamos. Isso desapareceu no Brasil independente. Com relação às penas estabelecidas pelo Código Criminal do Império, o estudo de Flávio Albuquerque aponta que, das 366 ocorrências, a pena de prisão com trabalho abarcou $32,5 \%$, seguida da de multa com $28,6 \%$, prisão simples com 21,04\%, ou seja, as penas com trabalho e simples perfazem um total de $53 \%$, confirmando o destaque da pena de privação de liberdade, que representava a nova concepção de punição defendida pelas novas ideias penitenciárias. O restante das penas se apresenta da seguinte forma: suspensão do emprego, 7,1\%; perda do emprego, 4,6\%; galés, $3 \%$; desterro, $1,3 \%$; morte, $0,82 \%$; degredo $0,5 \%$; açoite $0,2 \%$. A pena de banimento, embora prevista no Artigo 50 , não foi aplicada a nenhum crime. ${ }^{26}$

O Código também estabeleceu que a prisão com trabalho fosse cumprida em prisões específicas, ou seja, nas casas de correção, esperando que estas contassem com as oficinas de trabalho. Como nessa época essas instituições ainda não existiam no Brasil, o Código orientou, no seu Artigo 49, que a prisão com trabalho fosse comutada para a de prisão simples. ${ }^{27}$ Vimos acima, que as penas de prisão simples e com trabalho representavam $53,5 \%$ das ocorrências do

24 Sobre a reforma prisional na Bahia e a legislação brasileira, ver Trindade, "A reforma prisional na Bahia oitocentista". Ver também, Albuquerque Neto, "A reforma prisional no Recife oitocentista", pp. 27-51.

25 Edmundo Campos Coelho, As profissões imperiais, p.156.

26 Flávio de Sá Albuquerque Neto, "A reforma prisional no Recife oitocentista”, p. 44.

27 "Artigo 49. Enquanto se não estabelecerem as prisões com as comodidades e arranjos necessários para o trabalho dos réus, as penas de prisão com trabalho serão substituídas pela de prisão simples, acrescentando em tal caso a esta mais a sexta parte do tempo por que aquelas deveriam impor-se". Figueiras Junior, Código Criminal do Império, pp. 36 -37. 
Código Criminal o que demandou um crescimento do número de cadeias. Isso se deu na Bahia, e deve ser visto como causa da ampliação do sistema prisional de Salvador na primeira metade do século XIX, até que a penitenciária fosse construída.

Nem mesmo no berço da reforma prisional a construção das penitenciárias rompeu com as práticas punitivas do Antigo Regime, uma vez que a pena de morte e a deportação continuaram a ser aplicadas. ${ }^{28}$ Até mesmo Foucault, que defende a ruptura das práticas da punição entre o Antigo Regime e o Estado liberal moderno, identificou "as raízes da moderna disciplina da prisão nos regulamentos do século XVI e XVII para hospitais, exército, escolas e casas de correção". ${ }^{29}$ Daí sua observação de que a prisão "é menos recente do que se diz quando se faz datar seu nascimento dos novos códigos". Mas o autor também reconhece que "no fim do século XVIII e princípio do século XIX se dá a passagem a uma penalidade de detenção [...]; e era coisa nova". ${ }^{31}$

\section{As cadeias da cidade de Salvador}

No subsolo da Câmara Municipal de Salvador funcionava a cadeia da Relação, a primeira da cidade e a mais antiga da província. Em 1641, já se tem notícia de sua existência quando, em 10 de maio, foram presos na Relação negros trazidos de um mocambo para "se entregarem aos seus donos pagando dez mil [reis] por cada um". Duas

28 Ver, por exemplo, a "Mesa redonda de 20 de maio de 1978" em que participaram Michel Foucault, Catherine Duprat, Jacques Leonard, Michelle Perrot, Jacques Revel, Carlo Ginzburg, entre outros. Uma das questões debatidas e apresentadas a Foucault, contrapondo sua ideia de ruptura das práticas de punição, foi a subsistência na França, no decorrer no século XIX, da pena de morte, deportação etc. Michelle Perrot (org.), L'Impossible Prison, p. 40. A permanência de penas inerente ao regime monárquico absolutista também ocorreu em outros países. Para os Estados Unidos, ver David J. Rothman, "Perfecting the Prison", p.103; ver também Edward L. Ayers, Vengeance \& Justice: Crime and Punishment in the 19th-Century American South, Nova York, Oxford, 1984, pp. 34-72.

29 Gibson, "Global Perspectives on the Birth of the Prison", p. 1042, nota 7.

30 Foucault, Vigiar e punir, p. 207.

31 Idem, p. 207. 
décadas mais tarde, em 1665, os oficiais da Câmara da Bahia solicitaram ao Conselho Ultramarino verbas para obras na cidade e incluíram a construção da cadeia e do pelourinho, o que leva a supor que, até então, a cadeia funcionava em instalações ainda improvisadas. Somente em 1845 ela mudou de endereço ao ser transferida para a fortaleza do Barbalho, que passou a chamar-se Cadeia do Barbalho até ser, definitivamente, desativada em $1864 .{ }^{32}$

Outra cadeia era a do Aljube, localizada na antiga Ladeira do Aljube, nas imediações onde hoje está o viaduto da Sé, esquina com a ladeira da Praça. Esteve em atividade no período de 1833 a 1861. Nesse mesmo prédio funcionou a cadeia eclesiástica, também de nome Aljube, construída no século XVIII e desativada em 1832, ocasião em que o edifício foi alugado ao governo da província. ${ }^{33}$ Por último, a Casa de Correção, inaugurada em 1832 no forte de Santo Antônio Além do Carmo, localizado na Freguesia que levava o mesmo nome da fortaleza. Nas primeiras décadas do século XX passou a chamar-se Casa de Detenção e ali funcionou até a década de 1970. Vale destacar que as inúmeras fortalezas da cidade também serviam de prisão militar, geralmente destinadas a militares e presos políticos. Nas primeiras décadas do século XIX, existiam também os navios prisões, incluindo a Presiganga. ${ }^{34}$

As cadeias foram deslocadas da área urbana para a periferia da cidade como parte de medidas modernizadoras típicas da época. Com a inauguração da CPCT algumas cadeias foram desativadas e, a partir de 1865, o complexo prisional de Salvador ficou reduzido a duas instituições carcerárias, a CPCT e a Casa de Correção. A

32 AHU, Lisboa. Cx. 12. Doc. 1871. Fl. 12. [21.07.1621]. Agradeço a Pablo Antônio Iglesias Magalhães que, gentilmente, enviou-me essa documentação. Sobre a transferência da Cadeia da Relação para o Forte do Barbalho e sua desativação em 1864, ver Carcereiro João Caetano Martins para o chefe de polícia, 20 de julho de 1863, APEBa, Polícia, Relação de Presos, maço 6272; Fala que recitou o presidente da província da Bahia, o conselheiro Antonio Ignacio 'Azevedo, na abertura da Assembleia Legislativa da mesma província em 2 de fevereiro de 1847. Bahia, Typ. do Guaycurú de D. Guedes Cabral, 1847, p. 41.

33 Cândido da Costa e Silva, Os segadores e a messe: o clero oitocentista na Bahia. Salvador, SCT, EDUFBA, 2000, p. 125, 180, passim.

$34 \mathrm{Na}$ minha dissertação de mestrado, faço um estudo detalhado das cadeias de Salvador na primeira metade do século XIX, inclusive as militares e os navios prisões, posteriormente publicada em Trindade, "A reforma prisional na Bahia oitocentista", e "A Casa de Prisão com Trabalho da Bahia, 1832-1865”, cap.1. 
primeira servindo, principalmente, para não sentenciados; e a outra para os sentenciados. Esse quadro continuou assim até o final do século XIX.

\section{A Casa de Prisão com Trabalho: a primeira penitenciária da Bahia}

A CPCT começou a ser construída em 1832 e foi inaugurada em outubro de 1861, numa área pantanosa na freguesia da Nossa Senhora da Penha de França de Itapagipe, então periferia da cidade de Salvador. Em 1870, essa freguesia foi desmembrada e a instituição passou a pertencer à Freguesia de Nossa Senhora dos Mares. ${ }^{35} \mathrm{O}$ terreno correspondia a "100 braças quadradas" localizado "na marinha fronteira ao Engenho da Conceição, pelos fundos da Capela dos Mares". ${ }^{36}$ A planta original, projetada pelo arquiteto Pedro Weyll, foi inspirada na penitenciária de Ghent, na Bélgica, e previa um edifício panóptico octogonal (com oito raios) e uma casa central. No entanto, foram construídos apenas dois raios. ${ }^{37}$

No dia 31 de outubro de 1861, a CPCT começou a receber sentenciados transferidos da cadeia do Aljube, que estava sendo

35 Atualmente, a região é conhecida com Baixa do Fiscal, e no edifício da antiga prisão funciona o Hospital de Custódia e Tratamento do Estado da Bahia. Sobre as Freguesias do Arcebispado de São Salvador da Bahia no período de 1549 a 1889, ver Cândido da Costa e Silva, Os segadores e a messe, pp. 67-73; ver também Ana Amélia Vieira Nascimento, Dez freguesias da Cidade de Salvador, Salvador, Fundação Cultural do Estado da Bahia, 1986.

36 Sistema penitenciário. Relatório feito em nome da comissão encarregada, pelo Exigentíssimo senhor Presidente da Província, de examinar as questões relativas à Casa de Prisão com Trabalho, Bahia, Typographia de Galdino Joze Bizerra e Companhia, 1847, p. 5. Biblioteca do Mosteiro de São Bento, setor de obras raras. Agradeço a João Reis pela localização deste documento.

37 Não localizei a planta original da instituição, mas ela foi constantemente discutida com detalhes nos relatórios de presidentes da província e correspondências oficiais. Entretanto, a descrição mais detalhada está na tese de doutoramento de João Barbosa de Oliveira As prisões do pais: o sistema penitencial, ou higiene penal, Tese apresentada, e sustentada perante a Faculdade de Medicina da Bahia, em 11 de dezembro de 1843, Bahia, Typ. de L. A. Portella e Companhia, 1843, p. 41. 
extinta na mesma data, da Cadeia do Barbalho e da Cadeia de Correção. Nessa época, apenas um raio estava finalizado. Nem mesmo o pátio estava aterrado, o que impedia os presos de saírem das celas para se exercitar ou tomar sol. Somente em 1863, ambos os raios foram "finalmente concluídos e preparados de melhor modo", sob a administração do presidente da província Sá e Albuquerque. ${ }^{38}$ Algumas autoridades contemporâneas, como o chefe de polícia Flanklin Americo de Menezes Doria, consideram o ano de 1863 como a data oficial da inauguração da CPCT, mas desde 1861 a instituição já recebia presos, sendo a maioria sentenciada a prisão com trabalho. ${ }^{39}$

\section{O regulamento}

De outubro de 1861 até 1863 as normas da CPCT foram regidas pelo Decreto de 6 de julho de 1850, "na parte relativa do regime interno das prisões e segurança dos presos", e complementadas pelas disposições do Regulamento $120 .^{40}$ Esse mesmo decreto foi adotado como regulamento da Casa de Correção do Rio de Janeiro, que também foi seguido, com algumas alterações, pela Casa de Correção de São Paulo. Em 14 de outubro de 1863, a Bahia inovou ao implantar um regulamento próprio para a CPCT, com significativas diferenças em relação ao modelo da Corte, que era bem mais rígido. Tomemos como exemplo as regras de visitação. $\mathrm{Na}$

38 "Relatório do chefe de polícia Flanklin Americo de Menezes Doria", p.15, in Documentos anexos ao Relatório com que abriu a Assembleia Legislativa Provincial da Bahia o Excelentíssimo senhor doutor José Bonifácio Nascentes da Azambuja no dia $1^{\circ}$ de março de 1868 , Bahia, Typographia de Tourinho \& Cia, 1868.

39 Idem.

40 Chefe de Polícia para o carcereiro da Cadeia da Conceição, 14 de julho de 1862 , APEBa, Polícia, Casa de Prisão, maço 5925. O decreto $n^{\circ} 678$ de 6 de julho de 1850 foi adotado como regulamento da Casa de Correção do Rio de Janeiro, que também foi seguido, com algumas alterações, pela Casa de Correção de São Paulo. A Bahia tratou logo de fazer um regulamento próprio, que passou a vigorar em outubro de 1863. O Regulamento $\mathrm{n}^{\circ} 120$ de 31 de janeiro de 1842 regulou a execução da parte policial e criminal da Lei $n^{\circ} 261$ de 3 de Dezembro de 1841 que reformou o Código do Processo Criminal. 
penitenciária da Corte os presos de primeira classe poderiam receber visita de pais e filhos de dois em dois meses, os de segunda e terceira uma vez ao mês. ${ }^{41}$ Entendamos o sistema de classes, que estava relacionado ao comportamento do preso. Na primeira ficavam os presos considerados de pior comportamento, a segunda era intermediária, e os tidos como bem comportados pertenciam à terceira classe. ${ }^{42}$ Esse tipo classificação funcionou na penitenciária baiana até a implantação de regulamento próprio. Era um sistema que rotulava ao mesmo tempo em que punia e concedia privilégios. Estar na terceira classe, por exemplo, podia significar a possibilidade de transitar livremente dentro da instituição, e ser contratado para serviços internos remunerados, tão disputados entre os presos. ${ }^{43}$

$\mathrm{O}$ regulamento da CPCT de 1863 trouxe regras mais brandas para a visitação dos presos:

Art. 18. Também poderão os presos receber visitas ou falar nas grades com seus parentes e amigos, das 10 horas da manhã ao meio dia, e das 3 às 5 da tarde, precedendo licença do administrador.

Art. 19. Aos presos condenados não será permitida a licença, de que trata o artigo antecedente, mais de uma vez na semana: aos outros, porém, poderá ser dada todos os dias. ${ }^{44}$

Enquanto na Corte se concedia ao preso de bom comportamento o direito de receber visita uma vez ao mês, e somente de pais e filhos, a penitenciária baiana liberava o sentenciado, independente do seu comportamento, para receber amigos e parentes

41 Decreto $\mathrm{n}^{\circ} 678$ de 6 de julho de 1850 , Artigos 12, 22 e 27.

42 Idem, capítulo II, da disciplina das classes, pp. 33-35.

43 Sobre a divisão por classes na penitenciária da Corte, ver Aquino Pessoa, "Trabalho e resistência na penitenciária da Corte", p.85.

44 Regulamento da Casa de Prisão com Trabalho da Bahia aprovado pelo presidente da provincia o conselheiro Antonio Coelho de Sá e Albuquerque em 14 de outubro de 1863, Bahia, Typ. Poggetti - de Tourinho, Dias \& C, 1863, Capítulo II, "Da polícia nas prisões", p. 6. Exceto quando indicado, atualizei a grafia das palavras nos documentos manuscritos e impressos transcritos no texto, mas mantive-a original nos nomes próprios. 
uma vez na semana. Uma diferença significativa. Antes da implantação do regulamento próprio, os presos da CPCT foram proibidos de receber visitas de familiares e amigos. Eles reagiram protestando com petições coletivas endereçadas às autoridades. É possível que o afrouxamento de algumas normas do regulamento tenha sido fruto de negociação. Em uma das petições os presos argumentaram que, "ali o Pai não pode ver ao filho porque não lhe é permitido este direito nem o marido a mulher nem esta aquele nem a mãe o seu filho! Excelentíssimo Senhor morrer seria melhor". ${ }^{45}$ Essas linhas foram extraídas de uma extensa correspondência, escrita, em 1862, pelo preso João Byspo da Neves, que assinou "por mim e meus companheiros". ${ }^{46}$ Neves era pardo, na época com 47 anos, roceiro, natural da Vila do Conde, cumpria pena por crime de morte, e faleceu de pneumonia alguns meses depois, em 5 de outubro, no Hospital de Caridade. ${ }^{47}$ Essa petição coletiva, com seis páginas, inaugura na CPCT a prática da escrita como a principal forma de protesto. A escrita já era utilizada pelos presos das cadeias, mas não com a especificidade do discurso que veio a ser produzido pelos presos da penitenciária.

A proibição da visita era algo novo para os presos transferidos à CPCT na época da inauguração. Todos vieram transferidos da cadeia do Aljube, da cadeia do Barbalho e da Correção, onde não havia o rigor que o sistema penitenciário tentava implantar na nova instituição. Já nos tempos coloniais, quando a prisão não tinha um projeto reformador, era comum o cotidiano contato com amigos e parentes. Affonso de Taunay registrou, na Capitania de São Paulo, a construção de uma calçada de pedra que rodeava a cadeia pública, proporcionando maior conforto aos "visitantes dos prisioneiros que viviam, como de praxe, dependurados às grades das suas enxovias a conversar com parentes e amigos. ${ }^{48} \mathrm{Na}$

45 João Byspo das Neves para o presidente da província, março de 1862, APEBa, Polícia, Casa de Prisão, maço 3082.

46 Idem.

47 "Presos de Justiça", Livro 1136, ASCMB, p. 119.

48 Affonso de E. Taunay, Historia Social da Cidade de São Paulo no século XIX , 1801-1822, vol. 3, São Paulo, Depto. de Cultura, 1956, p.237, citado em Fernando A. Salla, "O encarceramento em São Paulo: das enxovias à penitenciária do Estado" (Tese de Doutorado em Sociologia, Universidade de São Paulo, 1997), p.24. 
Bahia, contato dessa natureza foi registrado na cadeia da Relação, quando o boticário João Ladislau de Figueiredo Mello "conversava da rua com o amigo encarcerado [Cipriano Barata], separados pelas grades e sob a vista do carcereiro que olhava da janela". ${ }^{49}$ As cadeias faziam parte do cenário citadino, o que facilitava ainda mais a interação do preso com o espaço extramuros. Lembrando que essa não foi uma exclusividade do Brasil, pois era um costume também das prisões europeias desde o período pré-moderno.

O controle rigoroso da visitação estava de acordo com as normas penitenciárias, que previa visitas, porém, de pessoas que pudessem contribuir com o processo de regeneração dos condenados - pessoas religiosas que trouxessem "boas influências". Isso excluía as relações pessoais anteriores ao ingresso na prisão. Pelo visto, o regulamento de 1863 veio amenizar parte do desejado isolamento dos presos e contrariar o rigor estipulado pelos reformadores. E. P Thompson discute como os costumes podem levar as pessoas a entrar em conflito com a lei que, para servir de mediadora nas relações de classes, precisa ter sua lógica própria. ${ }^{50}$ Guardadas as devidas proporções, entre a Inglaterra do século XVIII, contexto da discussão de Thompson, e a Bahia oitocentista, o regulamento da prisão precisava ser legitimado, caso contrário não funcionaria. As brechas que constam no regulamento da CPCT nada têm a ver com atitudes humanitárias, eram, sim, resultado de negociação que visava garantir um mínimo de tranquilidade no seio da comunidade prisional. Não interessava a nenhuma das partes o rompimento da ordem.

\section{Administração}

Funcionários e guardas faziam parte da vida diária dos presos, atuando como parceiros ou algozes, a depender do tipo de

49 Marco Morel, Cipriano Barata na Sentinela da Liberdade, Salvador, Academia de Letras da Bahia; Assembleia legislativa do Estado da Bahia, 2001, p.78.

50 E. P. Thompson, Senhores e caçadores, Rio de Janeiro, Paz e Terra, pp. 352-353. 
relação construída entre membros de ambos os grupos. ${ }^{51}$ A CPCT contava com um administrador e seu ajudante, um escrivão, um capelão, um médico, dois enfermeiros, um barbeiro e doze guardas. Havia também os soldados do destacamento e os mestres das oficinas, sendo que estes não eram funcionários públicos mas trabalhavam regularmente na instituição.

No topo da administração estava o chefe de polícia, que não era um funcionário da Casa, naturalmente, mas era quem dirigia a prisão e dava sempre a última palavra sobre assuntos prisionais, como autoridade máxima nos assuntos policiais da província. Nomeado pelo presidente da província entre desembargadores e juízes de direito, a chefia de polícia era um cargo de muito prestígio e poder no Império. ${ }^{52} \mathrm{O}$ administrador mantinha o chefe de polícia informado de toda a rotina da penitenciária e a maioria dos procedimentos dependia de sua autorização. A documentação revelou sua influência direta na administração diária da instituição, o que nos leva a refletir sobre o longo processo de implantação das ideias penitenciárias. Na Bahia, como em outros locais, foi preciso reunir estudiosos de áreas específicas na tentativa de implantar o aprisionamento moderno. ${ }^{53}$ Ao dar início a suas atividades, a direção do regime penitenciário terminou concentrada nas mãos do chefe de polícia que detinha a última palavra nas três áreas de conhecimento envolvidas com o debate da reforma prisional: na seara médica, podia divergir da prescrição dada ao preso em qualquer tempo; na engenharia, decidia sobre as construções e reparos e se estes deveriam ser feitos ou não; no campo das leis, muitas vezes mandava soltar, castigar, prender sem

51 Uma interessante discussão sobre a parceria entre presos e guardas, ou funcionários da prisão, está em Pawel Moczydlowski, The Hidden Life of Polish Prisons, Bloomington e Indianapolis, Indiana University Press, 1992, capítulo 7

52 Sobre as atribuições do chefe de polícia, ver Regulamento $\mathrm{n}^{\circ} 120$ de 31 de janeiro de 1842; Lei $n^{\circ} 361$ de 3 de dezembro de 1841; Thomas H. Holloway, Polícia no Rio de Janeiro: repressão e resistência numa cidade do século XIX, Rio de Janeiro, Fundação Getúlio Vargas, 1997, p. 158. Sobre a estrutura do aparato policial da Bahia na segunda metade do século XIX, ver resumo em João José Reis, Domingos Sodré, um sacerdote africano: escravidão, liberdade e candomblé na Bahia do século XIX, São Paulo, Companhia das Letras, 2008, p. 22.

53 Por exemplo, o principal documento que discute a implantação da penitenciária na Bahia foi elaborado por uma comissão composta de profissionais de medicina, engenharia e direito, Sistema penitenciário. Relatório feito em nome da comissão encarregada, pelo Excelentíssimo senhor Presidente da Província, de examinar as questões relativas a Casa de Prisão com Trabalho da Bahia. 
provas etc. O regulamento da CPCT, elaborado pela polícia, consumava o seu poder de decisão. Os trabalhos de Fernando Salla e Gláucia Pessoa não demonstram uma atuação predominante do chefe de polícia na administração diária das casas de correção de São Paulo e Rio de Janeiro. Os autores destacam a autoridade do diretor. ${ }^{54}$ É provável que essa questão tenha sido outra particularidade da penitenciária baiana. A CPCT não tinha a figura do diretor e sim do administrador. $\mathrm{Na}$ Bahia, o administrador era nomeado pelo presidente da província e recebia ordens diretamente do chefe de polícia. Os advogados Lucio Bento Cardozo, Catão Guerreiro de Castro e Valentim Antonio da Rocha Bittencourt, coronel Leovigildo Azevedo Monteiro, capitão Manoel de Castro Lima, tenente-coronel Manoel Diniz Vilas Boas, Emigdio José Cunha, Carlos Manoel da Silva, João José da Rocha foram os primeiros administradores da instituição.

\section{Segurança}

No início, o corpo da guarda era composto por dez homens, passando para doze em 1865. O regulamento mandava requisitar homens que soubessem ler e escrever, de preferência solteiros ou viúvos, sem filhos, "homens fortes, sadios e ativos". ${ }^{55}$ Mas na prática, este quesito também encontrou dificuldades para ser atendido, pois nem sempre encontravam-se candidatos com esse perfil. A documentação revela uma grande rotatividade entre os guardas, principalmente no final da década de 1860 e na seguinte, período de muitos pedidos de afastamento por motivo de doença. Um deles foi o do guarda Gonçalo Fernandes de Oliveira Vianna que, em 1873, foi

54 Sobre a administração da Casa de Correção de São Paulo ver Salla, As prisões de São Paulo, pp.103-112; sobre a da Corte, ver Pessoa, "Trabalho e resistência na penitenciária da Corte", capítulo 3 e 4.

55 Regulamento da Casa de Prisão com Trabalho, Titulo 2, Capítulo I- Dos empregados suas nomeações e atribuições, pp.15-16. 
afastado por três meses para tratar da saúde, conforme atestado informando estar ele com "febre intermitente". ${ }^{56}$ Essa era uma das denominações utilizadas para definir a malária, uma doença infectoparasítica que acometeu também alguns dos presos. Não era epidêmica, mas tornou-se uma doença endêmica na penitenciária, uma vez que há relatos dela pelo menos nas três primeiras décadas de atividade da instituição. No ano de 1869, foram 47 casos da doença e uma morte num universo de 359 ocorrências na enfermaria. ${ }^{57}$ Em 1871, o presidente da província alertou que o número de doentes aumentara de 198 para 265 até o final daquele ano, e que a "febre intermitente" seria a grande responsável, seguida de doenças respiratórias. ${ }^{58}$ É provável que a incidência dessa doença estivesse relacionada ao terreno pantanoso que circundava a instituição, onde o acúmulo de água salgada e água doce era a combinação perfeita para a proliferação do mosquito transmissor da doença. Aliás, os pântanos não se restringiam somente à área externa. Em 1869, ainda se falava em ampliar os portões de entrada para que os carros carregados de barro utilizados no aterramento interno tivessem acesso com mais facilidade. $^{59}$

Em 1871, numa tentativa de reduzir gastos, o barão de São Lourenço, então presidente da província, sugeriu uma série de mudanças na administração da penitenciária, com destaque na segurança, mais especificamente no que ele chamou de "pessoal armado para repelir a violência". Segundo o barão, além dos doze guardas a penitenciária contava com um destacamento de "quarenta praças do Corpo Policial, incluindo um oficial, um sargento, dois

56 Gonçalo Fernandes de Oliveira Vianna para o presidente da província, 12 de julho de 1873, APEBa, Presidência da Província, Casa de Prisão, maço 3087. Nesse maço é possível observar inúmeras petições de guardas, algumas com atestado médico, solicitando licença por motivo de doença.

57 "Movimento da Enfermaria da Casa de Prisão com Trabalho do $1^{\circ}$ de janeiro a 31 de dezembro de 1869 organizado pelo Dr. João Ferreira de Bittencourt e Sá, médico do estabelecimento", anexo ao Relatório apresentado a Assembleia legislativa da Bahia pelo excelentíssimo Senhor Barão de S. Lourenço, presidente da mesma província, em 6 de março de 1870, Bahia, Typographia do Jornal da Bahia, 1870, mapa 8.

58 Fala com que o excelentíssimo senhor desembargador João Antonio de Araujo Freitas Henriques abriu a $1^{\mathrm{a}}$ sessão da $19^{\mathrm{a}}$ legislatura da Assembleia Provincial da Bahia em $1^{\circ}$ de Março de 1872, Bahia, Typographia do Correio da Bahia, 1872, p. 47.

59 Administrador da CPCT para o chefe de polícia, 3 de setembro de 1869, APEBa, Governo da Província, Chefes de Polícia, maço 2963. 
cabos e um corneta", que custariam aos cofres públicos vinte contos de réis anuais. A sugestão era aumentar de doze para trinta o número de guardas e acrescentar ao quadro um comandante e, com isso, dispensar o uso do destacamento. O salário dos guardas continuaria a ser $500 \$ 000$ anuais e do comandante o dobro. ${ }^{60}$ Além do custo elevado, outros inconvenientes foram apontados pelo barão de São Lourenço. Um deles foi a saúde dos soldados que, constantemente, adoeciam por conta das febres, e "tendo-se dado já casos fatais" devido à insalubridade do local. Outro motivo apontado foi a falta de soldados para o policiamento na cidade. Segundo ele, havia seis companhias do Corpo Policial, sendo que três serviam no interior, policiando cada uma mais de 120 léguas, o que equivale, aproximadamente, a 600 quilômetros quadrados. As outras três companhias cuidavam da capital e das cidades e povoações do litoral, até Caravelas. Concluiu o barão que, diante desse quadro, não era possível continuar dispondo de quarenta soldados somente para a penitenciária. ${ }^{61}$ Isso sugere uma insuficiência do aparelho repressor na cidade. Se tais mudanças na segurança foram, de fato, adotadas elas sofreram novas alterações com o passar do tempo, pois documentos posteriores sugerem que os soldados do Corpo Policial continuariam atuando do lado externo da prisão. ${ }^{62}$

Sobre a rotatividade dos guardas, muitos pediam exoneração sem motivo aparente, enquanto outros eram exonerados por indisciplina. Os guardas da CPCT eram alvo constante de reclamações dos superiores e dos próprios presos. Casos de faltas e de saídas não justificadas e de corrupção envolvendo presos eram

60 A partir de 1863, o poder de compra de um trabalhador com salário anual de $400 \$ 000$ réis, com uma família de cinco membros, era suficiente para os gastos essenciais, como vestuário, alimentação e moradia. Kátia M. de Queiros Mattoso, Bahia: a cidade do Salvador e seu mercado, pp. 576-577.

61 "Cópia do Ato do Barão de São Lourenço para redução de despesas da CPCT, 21 de janeiro de 1871", APEBa, Polícia, Casa de Prisão, maço 5932. Para termos uma ideia de números, o $3^{\circ}$ e $4^{\circ}$ Batalhões da Guarda Nacional, aquartelados no Quartel do Comando das Armas em dezembro de 1869 , somavam 330 homens, dos quais quarenta eram mandados, diariamente, para a penitenciária, "Mapa demonstrativo da força dos Corpos da Guarda nacional aquartelados", 22 de dezembro de 1869, APEBa, Governo da Província, Correspondência recebida da polícia, maço 3139-37.

62 Ver, por exemplo, o relatório do Administrador Valentim Antonio da Rocha Bittencourt para o chefe de polícia, 1 de março de 1884, APEBa, Polícia, Mapa de Presos, maço 6276 . 
frequentes. Ao mesmo tempo, a documentação revela que a vaga de guarda da prisão era muito disputada. ${ }^{63}$ Muitos pedidos para a vaga de guarda ocorreram nos anos de 1869 a 1871, período que coincide com as secas no sertão baiano e a migração em massa para a capital, o que aumentava a procura por emprego. Por outro lado, a função de guarda tinha o atrativo do emprego público e assalariado, o que constituía um privilégio, como observou a historiadora Kátia Mattoso. ${ }^{64}$

Naquela época não existia nenhum treinamento específico para um guarda que atuasse na penitenciária, função específica e nova no então sistema prisional baiano. Os candidatos geralmente se apresentavam como pessoas pobres, com famílias numerosas, muitos deles militares reformados e ex-combatentes da guerra do Paraguai. Como foi o caso de "Francisco Joaquim das Chagas Pimentel, extenente de voluntários da pátria, casado, com três filhos, [que] vem a V. $\mathrm{Ex}^{\mathrm{a}}$. com os documentos juntos, implorar a graça de ser nomeado para uma das vagas de guarda da casa de prisão com trabalhos, visto o suplicante precisar de pão para si e sua família”. Francisco conseguiu a vaga em julho de $1871 .{ }^{65}$ Um mês antes, o alferes honorário do Exército, Euthechio Pires Figueiredo, que se declarou "casado e sem meios de subsistência", também havia conseguido uma vaga. ${ }^{66}$ Esse perfil militar dos guardas devia-se a um Ato do Governo da Província, de 21 de janeiro de 1871, que criou uma Companhia de Guardas para a CPCT preferindo "praças que tivessem serviços de guerra", uma maneira de reintegrar os veteranos do recente conflito, evitando que pudessem vir a ser fator de tensão social. ${ }^{67} \mathrm{Em} \mathrm{1873}$, por

63 Muitos dos ofícios de candidatos à vaga de guarda podem ser visto em APEBa, Presidência da Província, Casa de Prisão, maço 3085.

64 Mattoso, Bahia: a cidade do Salvador e seu mercado, p. 372.

65 Francisco Joaquim das Chagas Pimentel para o presidente da província, 17 de julho de 1871, APEBa, Polícia, Casa de Prisão, maço 3089.

66 Euthechio Pires Figueiredo para o presidente da província, 16 de maio de 1871, APEBa, Polícia, Casa de Prisão, maço 3089.

67 João Barreto de Souza Maia a rogo de Salustiano Manoel de Barros para o presidente da província, 26 de janeiro de 1871, APEBa, Polícia, Casa de Prisão, maço 3087. 
motivos orçamentários, a Companhia de Guardas foi substituída pela força policial com 28 praças e um oficial. ${ }^{68}$

Através do conteúdo dos pedidos de emprego pode-se perceber que os guardas eram pobres e, geralmente, com famílias numerosas para sustentar, portanto de condição social e financeira parecida com a dos presos. Talvez a situação de pobreza incentivasse as transações ilegais entre guardas e presos, como a agiotagem, negociação com mercadorias e venda de privilégios.

A dificuldade em administrar a guarda não foi exclusividade da Bahia. A Casa de Correção de São Paulo, por exemplo, também passou por problemas semelhantes. Para Fernando Salla, "tudo indica que os indivíduos que realizavam este serviço fossem completamente despreparados para o trabalho de vigilância e policiamento do estabelecimento". 99 No seu estudo sobre as prisões da Europa, Patricia O'Brien, da mesma forma, observou que os guardas pertenciam às mesmas origens sociais e classes dos presos, além de serem recrutados das patentes militares mais baixas. Assim como no Brasil, não havia nenhum tipo de treinamento especial para os guardas de prisão. Conforme a autora, no ano de 1872, um inquérito parlamentar na França discutiu o fracasso da reabilitação de presos e, como parte das medidas, recomendou-se a implantação de um treinamento especial para guardas de prisão. No Congresso Penitenciário Internacional, em 1879, foi votada e aceita a criação de escolas normais para instruir guardas de prisão. A experiência não funcionou na França nem em outros países da Europa. Nova tentativa foi feita em 1893, mas fracassou. Somente após a Segunda Guerra Mundial o projeto foi retomado como parte mais geral das reformas prisionais.

68 Fala dirigida a Assembleia Provincial da Bahia pelo primeiro vice-presidente desembargador João José de Almeida Couto no $1^{\circ}$ de março de 1873, Bahia, Tipografia do Correio da Bahia, 1873, p.14.

69 Salla, As prisões de São Paulo, p.104.

70 O'Brien, "The Prison on the Continent", p. 180. 


\section{Enfermaria}

Até o ano de 1868, os presos da CPCT recebiam assistência do médico da Câmara Municipal, que sem um lugar apropriado para tratar os doentes não tinha outra solução a não ser encaminhá-los para o Hospital da Caridade, administrado pela Santa Casa de Misericórdia. Essa rotina resultou num intenso movimento de presos entre a penitenciária e o hospital. Para ano de 1865, levantei 268 ocorrências entre internamentos e altas do hospital, correspondentes a movimentação de 119 presos. ${ }^{71}$ O regulamento oficial de 1863 previa um médico exclusivo do estabelecimento para dirigir a enfermaria, também exclusiva. Essas medidas visavam, justamente, impedir a remoção de presos para o hospital, para onde deviam seguir somente em caso de epidemia, como ocorreu em 1870, quando muitos presos foram vítimas da varíola. O regulamento também dizia que o preso com melhor condição financeira podia optar por um médico particular, desde que a doença fosse atestada pelo médico da prisão. Não encontrei nada sobre a concretização de tal procedimento. Talvez essa cláusula tivesse sido pensada para beneficiar alguém de posição social mais elevada que viesse a fazer parte da população carcerária. $\mathrm{O}$ relatório penitenciário de 1847 defendia tratamento diferenciado para presos políticos, embora nada tivesse sido oficializado a esse respeito. ${ }^{72}$ Já os presos pobres não tinham opção senão entregar-se aos cuidados do médico da Casa. ${ }^{73}$ Os presos pobres eram aqueles que viviam à custa dos cofres provinciais, ou seja, a grande maioria, senão todos, pois todos buscavam um meio de fazer parte dessa lista, mesmo os que, supostamente, não precisavam. $\mathrm{O}$ preso pobre, além de ter o sustento e vestimenta garantidos, não precisava pagar pelos selos em documentos oficiais que porventura viesse emitir, como por exemplo, uma petição de graça ao imperador, entre outros.

71 Diversas guias de transferências de presos para o hospital e para a CPCT, APEBa, Polícia, Casa de Prisão (1861-1886), maço 5942.

72 Sistema Penitenciário. Relatório feito em nome da comissão encarregada, pelo Excelentíssimo senhor Presidente da Província, de examinar as questões relativas a Casa de Prisão com Trabalho da Bahia, p. 18

73 Regulamento da Casa de Prisão com Trabalho, Capítulo IV - Dos doentes e das enfermarias, p.12. 
Em 1867, consta a existência de uma enfermaria provisória numa das galerias, no raio onde ficavam as celas, sob a direção do doutor João Ferreira de Bittencourt Sá, médico oficial da CPCT. ${ }^{74}$ Aquele ambiente não era novo para ele. Em $1^{\circ}$ de fevereiro de 1856 , quando o edifício ainda se encontrava em construção, Bittencourt improvisou uma enfermaria no raio celular para tratar 313 africanos livres apreendidos no tráfico ilegal, todos muito debilitados pelos maus tratos que sofreram na travessia do Atlântico. A epidemia do cólera assolava a cidade de Salvador na época. Para agravar a situação, as chuvas de março inundaram o pátio da prisão, ainda em obras e com grande quantidade de entulho. O "depósito de materiais fecais" do raio onde estavam os africanos se encontrava abarrotado e sem condição de escoamento. ${ }^{75}$ Ambiente ideal para a contaminação colérica. Muitos africanos morreram da doença, assim como os soldados que faziam a vigilância. Médico e doentes ficaram isolados, ninguém se arriscava a aparecer por ali, nem mesmo para retirar os africanos em bom estado de saúde para distribuição nos trabalhos públicos da cidade. Bittencourt cuidou dos doentes até o fim da epidemia. No dia 11 de março foi divulgado o saldo: dos 313 africanos, 61 gozavam de boa saúde, 25 se encontravam na enfermaria, vinte estavam internados no hospital da Caridade, 67 distribuídos para os estabelecimentos públicos e 140 tinham morrido. ${ }^{76}$ O diretor da obra, Manoel de Santa Rita Portela, não deixou de elogiar o doutor Bittencourt ao chefe de polícia, dizendo que ele cuidara dos "africanos com todo o zelo". 77

Entretanto, posteriormente, seu atendimento na enfermaria da prisão não parecia assim tão zeloso, pelo menos na opinião dos presos doentes. Muitas vezes foi acusado de corrupção pelos pacientes mais prejudicados, geralmente os que ocupavam os degraus mais baixos da

74 No século XIX, o estudante de medicina tinha que apresentar uma tese de doutoramento para receber o diploma de médico.

75 Administrador Manoel de Santa Ritta Portela para o chefe de polícia, 31 de março de 1856, APEBa, Polícia, Mapa de Presos, maço 6270.

76Administrador Manoel de Santa Ritta Portela para o chefe de polícia, 11 de março de 1853, APEBa, Polícia, Mapa de Presos, maço 6270. Nessa época, a atividade do administrador nada tinha a ver com a função prisional, uma vez que CPCT ainda não recebia presos. Era denominado administrador a pessoa responsável pelo local, seja no cemitério, no hospital etc.

77 Manoel de Santa Ritta Portela para o chefe de polícia, 16 de abril de 1856, APEBa, Polícia, Mapa de presos, maço 6270. 
hierarquia social da prisão. Por exemplo, os presos o acusavam de não dar atendimento aos doentes miseráveis e de garantir melhor tratamento a outros que podiam pagá-lo ou, até mesmo, de prescrever dieta especial, mais generosa, saborosa e rica, para presos que sequer estavam doentes. Em março de 1868 o chefe de polícia, em documento anual, anexo ao relatório do presidente da província, tentou explicar um número de 491 doentes numa população prisional de 203 presos. Segundo ele, houve presos "que baixaram a enfermaria mais de uma vez". Ainda assim, são números elevados se comparados à nenhuma repercussão do assunto nas correspondências diárias entre o administrador e o chefe de polícia onde, certamente, essas taxas seriam comentadas, como aconteceu na época da epidemia da varíola. Essa estatística só aparecia nas listas internas e nos relatórios da presidência da província.

Entre as doenças apresentadas pelo chefe de polícia "sobressaem 80 casos de bronquite, 70 de febres intermitentes e 61 de indigestão". As doenças respiratórias geralmente eram ocasionadas pelo ambiente frio e úmido das celas, sobretudo na época das chuvas, quando certas áreas da prisão ficavam submersas, tornando o ambiente mais propício para essas doenças. A febre intermitente ou malária, como mencionado, tinha a ver com o ambiente pantanoso, que facilitava a procriação de mosquitos. Já os casos de "indigestão" decorriam da má alimentação, podendo estar relacionada ao estado de conservação dos alimentos ou à carência de vitaminas e proteínas. Segundo a Gazeta Médica de 1869, os casos de afecções gastrointestinais tinham aumentado no Hospital da Caridade e eram os presos da Cadeia da Correção e da CPCT os mais afetados, seguidos da população pobre em geral. ${ }^{78}$ Ainda no seu relatório, o chefe de polícia informou que faleceram três presos, um de tuberculose, um de anemia e outro de beribéri. ${ }^{79}$ Em 1870 foi aprovada uma verba de 1:224\$080 réis para a construção de uma enfermaria no terceiro pavimento do raio, onde ficavam as oficinas. ${ }^{80}$ Em 14 de outubro daquele mesmo ano, a nova enfermaria entrou em

78 Braga Rios, "Entre a vida e a morte", p.135.

79 "Relatório do chefe de polícia Flanklin Americo de Menezes Doria", p. 21.

80 Presidente da província para o administrador de CPCT, 22 de fevereiro de 1870, APEBa, Polícia, Casa de Prisão, maço 5931. 
funcionamento e teve seu regimento aprovado pelo presidente da província. ${ }^{81}$

O cuidado com a saúde e a alimentação dos presos foi uma característica do aprisionamento moderno. Fernando Picó observa essa mudança apontando o quanto os regulamentos das prisões demonstram preocupação com a qualidade da comida, a saúde, o exercício e a segurança pessoal do preso. ${ }^{82}$ Esses cuidados também podem ser observado no regulamento da CPCT.

\section{Escola de primeiras letras}

O discurso penitenciário incluía, além do trabalho, da religião e do isolamento do preso, a educação básica, chamadas de "primeiras letras". Em 1868, o chefe de polícia lamentava em seu relatório o fato de a CPCT ainda não ter uma escola "com frequência obrigatória para todos os presos". Mas sua proposta de educação para os presos tinha um limite que refletia o pensamento das elites da época: "a cultura da inteligência, embora em grau limitado, não pode deixar de entrar como elemento essencial no regime de um estabelecimento penitenciário, onde para melhorar o coração, há mister tempo de melhorar o espírito". A instrução dos presos, prevista na reforma prisional, era a educação básica, a mesma pensada para os pobres em geral. As classes desfavorecidas só tinham acesso ao ensino primário. Entretanto, com o avançar do século XIX, a demanda da mão de obra especializada facilitou o acesso aos cursos secundários. ${ }^{83}$ Já as universidades continuaram espaços privilegiados das elites.

81 Fala com que o excelentíssimo senhor desembarcador João Antonio de Araujo Freitas Henriques abrio a $1^{\mathrm{a}}$ sessão da $19^{\mathrm{a}}$ legislatura da Assembleia Provincial da Bahia em $1^{\circ}$ de Março de 1872, p. 46

82 Picó, El dia menos pensado, p.80.

83 Miguel Luiz da Conceição, “'O aprendizado da liberdade’: educação de escravos, libertos e ingênuos na Bahia oitocentista" (Dissertação de Mestrado em História, Universidade Federal da Bahia, 2007), p.46. Sobre a proposta de educação para os pobres na França, ver George Rudé, A Europa revolucionária, 1783-1815, Lisboa, Presença, 1988, p.198. 
Escreveu também o chefe de polícia que "a escola tem se tornado um dos mais belos realces das penitenciárias modernas". Ele citou como exemplo a penitenciária de Louvain, na Bélgica, "cuja escola ensina-se aos presos religião, moral, leitura, escrita, aritmética, e ainda noções elementares de gramática, história, geografia, elementos de geometria e desenho linear" ${ }^{84} \mathrm{O}$ chefe de polícia estava certo, as escolas para presos faziam parte do projeto reformador das prisões. Na Casa de Correção de São Paulo, por exemplo, em 1854, dois anos após sua inauguração, foi criada uma escola e como professor foi escolhido um sentenciado que antes de ser preso era professor de primeira letras. Ele foi destituído do cargo após quatro anos por "não ter força moral suficiente para reger esse magistério", conforme justificou o administrador. A escola da penitenciária de São Paulo teria prosperado, pois em 1887 quase todos os presos da penitenciária paulista sabiam ler. ${ }^{85}$

A escola de primeiras letras da CPCT foi criada em 15 de junho de 1871 e, segundo o presidente da província, João Antonio de Araujo Freitas Henriques, a iniciativa fora recebida "pelos presos com sumo contentamento". Para dirigir a escola foi nomeado o professor Benvindo Alves Barbosa, começando a ensinar no dia 15 de setembro daquele ano e permanecendo na função por dez anos. ${ }^{86}$

Diferente da penitenciária paulista, as autoridades baianas não permitiram sentenciados atuando como professores, mesmo tendo recebido duas propostas nesse sentido. Uma delas foi do sentenciado e professor Francisco Ribeiro de Seixas, que em julho de 1869 tentava garantir sua vaga antes da criação da escola e pediu "preferência para o lugar de professor para este estabelecimento, visto ser competentemente habilitado como provou com os documentos que juntou em sua petição". ${ }^{87}$ Seixas não recebeu resposta a seu

84 "Relatório do chefe de polícia Flanklin Americo de Menezes Doria", p. 20. Grifo

meu

85 Araújo Gonçalves, "Cadeia e Correção”, pp. 61-62.

86 Fala com que o excelentíssimo senhor desembargador João Antonio de Araujo Freitas Henriques abriu a $1^{\mathrm{a}}$ sessão da $19^{\mathrm{a}}$ legislatura da Assembleia Provincial da Bahia em $1^{\circ}$ de Março de 1872, p. 47; Administrador da CPCT para o chefe de polícia, 17 de novembro de 1871, APEBa, Governo da Província, Chefes de Polícia, maço 2965.

87 Francisco Ribeiro de Seixas para o chefe de polícia, $1^{\circ}$ de outubro de 1870, APEBa, Polícia, Assuntos Diversos, maço 6496. Esse preso foi contemplado com o estudo de sua trajetória em Cláudia Moraes Trindade, "Francisco Ribeiro de Seixas e vida prisional na Bahia oitocentista. 
pedido, tampouco os documentos comprobatórios de sua qualificação profissional foram devolvidos, uma vez que ele tentou reavê-los junto à presidência da província. Outro candidato foi o sentenciado Antonio Philadelpho Thomaz de Freitas, que dois meses após a criação da escola escreveu ao presidente da província. Seu pedido segue transcrito na íntegra.

Antonio Philadelpho Thomaz de Freitas, tendo sciencia que por Acto da Presidencia foi creada uma cadeira de Primeiras Letras na casa de prisão com trabalho para o fim louvável de diffundir-se a instrução aos infelizes alli recolhidos; e como esteja o Supplicante comprehendido no numero d'estes, cumprindo sentença de prisão simples, cuja pende ainda de recurso que intentou para o Supremo Tribunal de Justiça e julgando-se habilitado por estudos especiais que tem, para exercer satisfactoriamente o logar de professor d'essa eschola, vem com todo o respeito ante $\mathrm{V}$. Ex $\mathrm{x}^{\mathrm{a}}$ implorar a graça de ser provido n'elle mediante uma gratificação á arbitrio de V. Exa ${ }^{\mathrm{a}}$. Parece ao Supllicante que não deve ser estranhavel a sua supplica porque um precedente existe na penitenciaria da Côrte, que segundo jornaes d'esta Provincia de outubro de 1866, foi expedido um Aviso do Ministerio da Justiça mandando que o Director d'aquela penitenciaria contractasse um professor para a respectiva eschola, preferindo a algum dos presos que julgasse habilitado, mediante uma gratificação pecuniaria que se lhe daria. As vantagens que se colhe d'esta medida são immensas, quer pelo lado economico, pois é certo que o preso contentar-se há com um modica gratificação, ao que não se sujeitará um professor externo; quer ainda pelo lado da disciplina interna da casa, e conhecimento que já tem o preso, dos seus companheiros de infortunio. Confia portanto o suplicante que pelas razões expostas, e o mais que a esclarecida intelligencia de V.Ex. ${ }^{a}$ supprirá,

In: João José Reis e Elciene Azevedo (orgs.). Escravidão e suas sombras: ensaios de um grupo de pesquisa (Salvador, Edufba, 2012), pp. $233-278$. 
se dignará V.Ex. ${ }^{a}$ attender ao seo pedido, deferindo-lhe favoravelmente. ${ }^{88}$

O pedido foi indeferido. Não pelo presidente da província, mas pelo chefe de polícia, que ficou responsável pelo despacho. $\mathrm{O}$ argumento apresentado por Philadelpho, de conhecer seus "companheiros de infortúnio", pode ter sido um dos motivos que levaram as autoridades a recusar presos atuando como professor. $\mathrm{O}$ chefe de polícia conhecia muito bem a combinação entre presos e letramento, principalmente quando, ao ler o jornal, se deparava com denúncias de maus tratos enviadas por presos. Vale ressaltar que a prática da escrita entre os presos da CPCT já existia antes da criação da escola, portanto é incorreto relacionar a produção dessas cartas com o ensino das primeiras letras na CPCT, o que se confirma por uma quantidade maior de cartas no final da década de 1860 e início da de 1870, portanto antes do início das aulas.

Em maio de 1876, a penitenciária recebeu a visita do presidente da província que, em seu relatório, observou o "quanto é zeloso o professor daquela cadeira, que é frequentada pela maioria dos presos que para ali entram, muitos dos quais inteiramente analfabetos, e que hoje sabem regularmente ler e escrever". ${ }^{89}$ Alguns anos depois, o professor do presos, Benvindo Barbosa, relatou uma situação um tanto diferente. Existe pouca documentação sobre a escola, os poucos mapas de alunos que localizei são da década de 1880. Um deles informa que, em abril de 1882, frequentavam a escola 105 presos. ${ }^{90}$ Levando-se em conta que em janeiro desse mesmo ano o total de presos sustentados pelo governo, geralmente a totalidade, era 347, podemos supor que a frequência na escola não era

88 Antonio Philadelpho Thomaz de Freitas para o presidente da província, 16 de julho de 1871, APEBa, Polícia, Casa de Prisão, maço 3085.

89 "Relatório com que o excelentíssimo senhor presidente Dr. Luiz Antonio da Silva Nunes abriu a Assembleia Legislativa Provincial da Bahia no dia $1^{\circ}$ de maio de 1876 ", Bahia, Typographia do Jornal da Bahia, 1876, p.21.

90 Mapa mensal de abril de 1882 - contendo a relação dos alunos que frequentaram a escola da Casa de Prisão com Trabalho, procedimento, assiduidade, adiantamento, observações, 3 de maio de 1882, APEBa, Polícia, Cadeias, maço 6279. 
obrigatória ou havia algum critério de seleção que desconheço. ${ }^{91}$ Nesse mesmo documento, o professor observava que os livros solicitados ao governo, através da Diretoria de Estudos, não haviam chegado e "conta-nos que não chegarão em virtude daquela diretoria não os possuir". O professor completou dizendo que os alunos " em geral não tem muita tendência aos estudos", que a "frequencia dessa escola é muito irregular pela necessidade de disciplina, pelo estado de saúde dos presos e finalmente pela falta de livros que atualmente se dá". No mapa, todos os alunos foram avaliados como assíduos, com procedimento bom e adiantamento regular. ${ }^{92}$

Uma notícia do jornal $O$ Alabama indica que não eram somente os alunos os únicos a faltarem à escola. A notícia dizia que o "professor deste estabelecimento [CPCT] dá aula quando lhe aprouver". O chefe de polícia pediu explicações ao administrador, que justificou as faltas do professor por motivo de moléstia e por estar estudando para o "concurso da cadeira dos Mares". ${ }^{93}$ Não localizei mais informações sobre esse caso. Sobre aquele primeiro professor, Benvindo Barbosa, sabe-se que em 1882 tinha uma escola na freguesia da Conceição da Praia que levava o seu nome. Entre seus alunos, um nome ilustre, o futuro rábula Cosme da Farias, então com seis anos de idade. ${ }^{94}$

Curiosamente, o volume documental sobre a escola primária da CPCT é tímido se comparado com o que trata de outras atividades rotineiras da prisão. As correspondências diárias da administração, assim como a dos presos, raramente mencionam a escola.

91 "Relação diária de presos pobres existentes nesta casa e sustentados pelo cofre público", 30 de janeiro de 1882, Polícia, Cadeias, maço 6279.

92 Idem.

93 Chefe de polícia para o administrador da CPCT, 5 de junho de 1882, APEBa, Polícia, Cadeias, maço, 6279.

94 Monica Celestino Santos, "Réus, analfabetos, trabalhadores e um major: a inserção social e política do parlamentar Cosme de Farias em Salvador" (Dissertação de Mestrado em História, Universidade Federal da Bahia, 2005), p. 18. 


\section{As oficinas de trabalho}

Em 1865, entraram em atividade as primeiras oficinas de trabalho da $\mathrm{CPCT}^{95}$ Durante uma visita do chefe de polícia à penitenciária, os presos protestaram por ficarem "encerrados dia e noite em uma cela", com "falta de ar e exercício". ${ }^{96}$ A essas reclamações somaram-se outras anteriores e ao processo de implantação das oficinas, que encontrava-se em atraso. Inicialmente, a ideia do chefe de polícia foi empregar presos que conhecessem algum ofício, e os demais na obra do aterro do pátio, em turmas de vinte ou trinta, com um "salário módico de duzentos a trezentos réis diários", que seriam pagos pelo arrematador da obra. ${ }^{97}$ Os trabalhadores receberiam metade dos seus salários, enquanto o restante seria guardado em "depósito ou em uma caixa" e, posteriormente, entregue aos presos depois de cumprida a sentença; ou à família, "quando a pena de prisão não fosse temporária, ou o preso falecesse". ${ }^{98} \mathrm{O}$ produto líquido do trabalho das oficinas seria dividido em quintos: um para a tesouraria da CPCT, dois para o mestre da oficina e dois para os presos. ${ }^{99}$

No dia 23 de outubro de 1865, teve início os primeiros ensaios na oficina de marceneiro com os presos José Raimundo, Antonio Manuel do Nascimento Silva Monte Negro, Manoel Constantino Cardoso e Avelino José Jerônimo. Esses presos operários, como se denominavam, tinham a tarefa de "fazer os moveis, precisos para montar as outras oficinas". ${ }^{100}$ Cinco dias depois, Avelino foi substituído por outro preso, o escravo Cassiano. O motivo do afastamento teria sido o seu "mau comportamento". ${ }^{101}$ Este podia ser os primeiros sinais de resistência à disciplina das oficinas

95 "Relatório do chefe de polícia Flanklin Americo de Menezes Doria", pp. 19-20.

96 Chefe de polícia para o presidente da província, 4 de setembro de 1865, APEBa, Governo da Província, Cadeias, maço 3082.

97 Arrematantes eram os particulares que firmavam contrato de serviços com a CPCT.

98 Idem.

99 "Relatório do chefe de polícia Flanklin Americo de Menezes Doria", p. 20.

100 Chefe de polícia para o administrador da CPCT, 23 de outubro de 1865, APEBa, Casa de Prisão, maço 5926.

101 Idem. 
prisionais. Quanto ao escravo Cassiano, sabemos que não cumpria pena de prisão com trabalho, pois o Código Criminal proibia que escravos recebessem esse tipo de sentença. A sua presença na oficina é mais um indício da adaptação do sistema penitenciário à realidade prisional da Bahia. Os mestres de oficio eram escolhidos entre os profissionais da cidade e o primeiro a assumir a oficina de marcenaria foi José Polibio da Rocha, que permaneceu no cargo por muitos anos. Em 1865, o valor de seu jornal era 1200 réis mais a terceira parte do produto manufaturado. ${ }^{102} \mathrm{Um}$ mês depois, assumiram os primeiros presos aprendizes, Bernardino Gil d'Andrade e João Mathias dos Santos.

Em seguida, começaram a funcionar as oficinas de alfaiate, sapateiro e carapina. Foram nomeados como mestres, respectivamente, Augusto do Amaral, o ex-guarda Braz Diogo das Chagas e Rufino Marques Carvalho. ${ }^{103} \mathrm{Na}$ oficina de sapateiro foram empregados dez presos. ${ }^{104}$ No início, a escolha da especialidade das oficinas estava relacionada aos produtos necessários à infraestrutura da penitenciária. $\mathrm{O}$ artigo 110 do regulamento previa a existência de "oficinas convenientes, preferindo-se as que menos complicadas forem e maior extração acharem os seus produtos". ${ }^{105}$ No Rio de Janeiro, a escolha das oficinas também foi ditada pela necessidade dos produtos. Segundo o diretor da penitenciária da Corte, Miranda Falcão, os presos deveriam "confeccionar aquilo, de que o estabelecimento tem necessidade". ${ }^{106}$ Em 1868, na Bahia, a oficina de carapina estava desativada enquanto que as de marceneiro, sapateiro, charuteiro e alfaiate, funcionavam plenamente. As duas últimas, desde 1866, quando assumiram, respectivamente, os mestres Antonio Manuel de Santana e João Gonçalves Barroso. ${ }^{107}$

102 Chefe de polícia para o administrador da CPCT, 3 de novembro de 1865, APEBa, Casa de Prisão, maço 5926.

103 Ofícios do chefe de polícia para o administrador, 27 de outubro; 7 e 22 de novembro de 1865, APEBa, Casa de Prisão, maço 5926.

104 Chefe de polícia para o administrador, 22 de novembro de 1865, APEBa, Polícia, Casa de Prisão, maço 5926.

105 Regulamento da Casa de Prisão com Trabalho da Bahia, Titulo 4, Do trabalho, Capítulo Único, art. 110.

106 Pessoa, "Trabalho e resistência na penitenciária da Corte, 1850-1876", pp. 90-91.

107 "Relatório do chefe de polícia Flanklin Americo de Menezes Doria", p. 19; chefe de polícia para o presidente da província, 3 de janeiro de 1866; chefe de polícia para o vice 
Em 1869, o Jornal da Bahia anunciava que as oficinas de charuteiro, sapateiro e marceneiro estavam em plena atividade, "cujos artefatos são vendidos a retalho e por atacado, e por menos do que em outra qualquer parte". ${ }^{108}$ Como vemos, as oficinas concorriam com o mercado de Salvador. O baixo custo anunciado sugere a exploração da mão de obra dos presos. Esse tipo de exploração ocorria também em outros países. Por exemplo, na França, por volta de 1840, em pleno processo industrial, os operários do segmento de luvas reagiram com greves e protestos contra o baixo custo da mão de obra penal. Eles acusavam o governo de incentivar o trabalho prisional e com isso contribuir com a redução dos salários dos demais trabalhadores. ${ }^{109}$

Para a Bahia, não encontrei manifestações nem notas no jornal que demonstrassem o descontentamento de mestres de ofício da cidade com a concorrência da mão de obra prisional. Além de fornecer produtos para as instituições provinciais, as oficinas da CPCT vendiam, regularmente, seus produtos para o atacado e o varejo. Em 1871, a oficina de sapateiro vendeu 356 pares de sapatos para o Arsenal de Guerra. ${ }^{110}$ No entanto, não era sempre que as oficinas da CPCT tinham o melhor preço da cidade. Em 1866, na ocasião em que as vendas aumentaram por conta da Guerra do Paraguai, a oficina de sapateiros perdeu uma concorrência de 1050 pares de botas para o comerciante João Salgueiro, que ofereceu melhor preço e qualidade. As botinas eram destinadas "aos contingentes da Guarda Nacional prestes a marchar para o Teatro da Guerra". A diretoria do Arsenal de Guerra reclamou ao presidente da província dos preços abusivos cobrados pelo administrador da penitenciária, na época Emilio de Oliveira. ${ }^{111}$

Em 1867, um escândalo financeiro envolvendo o administrador Manoel Diniz Vilas Boas gerou um volume maior de documentação sobre as oficinas, como listas de materiais de compras,

presidente da província, 18 de março de 1866, APEBa, Governo da Província, Chefes de Polícia, maço 3139-31.

108 Jornal da Bahia, 28/02/1868.

109 Foucault, Vigiar e punir, p. 215.

110 Chefe de polícia para o presidente da província, 26 de dezembro de 1871, APEBa, Polícia, Chefes de Polícia, maço 2965.

111 Tenente Coronel Cipriano da Rocha Lima para o presidente da província, 8 de novembro de 1866, APEBa, Governo da Província, maço 3139-33 
pagamento de presos e o próprio processo que incriminou Vilas Boas, além da demissão de alguns funcionários, como o ajudante Carlos Silva. Villas Boas foi acusado de desviar dos cofres da penitenciária a quantia de 1:485\$710 provenientes do faturamento das oficinas. ${ }^{112} \mathrm{O}$ administrador negou a acusação, alegando que estava sendo alvo de vingança por denunciar abusos nas oficinas e no restante da prisão. De fato Villas Boas tornara público as práticas ilegais, tanto dos presos como dos funcionários, como se pode observar na pequena amostra abaixo:

Os chefes das oficinas além de consócios na traficância expostas, tão impontuais, tão sem força e prestígio, que viviam em constante luta com a insubordinação e desrespeito dos presos operários das mesmas oficinas, seus discípulos. Condenados sem o menor vislumbre, já não digo de moral, mas ainda de respeito e de temor, entregues a toda casta de vícios, ao ócio, a ebriedade, ao jogo, e a impudicícia. ${ }^{113}$

A documentação leva a supor que Villas Boas fez uma administração cuidadosa nas oficinas. Acompanhava a compra da matéria prima, do pagamento dos presos operários, levantou irregularidades sobre o mestre da oficina de sapateiro, o ex- guarda da instituição Braz Diogo das Chagas, que terminou demitido. Não se sabe o que motivou o chefe de polícia a realizar uma fiscalização nos livros de escrituração das oficinas, quem sabe o aumento do faturamento ou alguma denúncia. $\mathrm{O}$ fato é que ele encontrou a escrituração atrasada, entre outras irregularidades. Villas Boas foi acusado de desvio de dinheiro, suspenso e depois exonerado, em 12 de fevereiro de 1868.

112 "Processo Crime de Manoel Diniz Villas Boas", APEBa, Judiciário, Processo Crime 20/708/11, fls. $9-14$ v.

113 Resposta apresentada pelo ex-administrador da Casa de Prisão com Trabalho da província da Bahia, tenente-coronel Manoel Diniz Villasboas, no processo de responsabilidade a que foi submentido por ato da presidência da mesma província de 12 de fevereiro de 1868, Bahia, Typographia Constitucional de França Guerra, 1868, p. 6. 
A marcenaria foi a mais próspera das oficinas, pelo menos é o que indica a documentação. A oficina supria o mobiliário das escolas da província. Em 18 de março de 1872, o almoxarife da penitenciária encaminhou para o administrador duas amostras das “ mobílias das aulas do sexo masculino das Freguesias de Passé e São Felix, para as mandar fazer com toda a brevidade, segurança e boas madeiras, conforme me tem sido ordenado, a fazer-lhe essa declaração". ${ }^{114}$ Ofícios como este e outros relacionados a pedidos e entregas de mobília escolar são inúmeros na documentação. Particulares também compravam móveis na marcenaria da prisão, como foi o caso do Dr. Emigdio Joaquim dos Santos que, em 6 de junho de 1867, adquiriu uma cama francesa envernizada, com lastro de madeira por $30 \$ 000$, um lastro para a mesma cama por $3 \$ 500$, dois lastros para outras camas por $7 \$ 000$ e um lavatório singelo no valor de $5 \$ 000 .^{115}$

O mestre marceneiro José Polibio da Rocha esteve no comando durante vinte e nove anos e foi um dos principais responsáveis pela prosperidade dessa oficina. Dentre os mestres de oficina da penitenciária, foi ele quem mais tempo ficou no cargo, teve maior visibilidade na documentação através de seus pleitos de aumento de salário, de condições de trabalho, de verbas para exposição. Parecia ser homem de confiança, pois seu nome aparece em vários documentos como testemunha de inventários de bens de presos falecidos, recibos, entre outros.

Em setembro de 1875, um pedido de José Polibio chama a atenção. Ele solicitou ao presidente da província para ser nomeado guarda no lugar do falecido Felippe da Silva Guimarães. A resposta veio numa única palavra: "prejudicado." 116 Não consegui nenhuma pista que justificasse tal pedido, além de possíveis ganhos oriundos de facilidades e privilégios negociados ilegalmente com presos. Já vimos acima que o salário de um guarda era inferior ao do mestre da

114 Almoxarife José Carlos Ferreira para o administrador da CPCT, 18 de março de 1872, APEBa, Polícia, Casa de Prisão, maço 5933.

115 Emigdio Joaquim dos Santos à Casa de Prisão com Trabalho, 6 de junho de 1867, APEBa, Polícia, Casa de Prisão, maço 5942.

116 José Polybio da Rocha para o presidente da província, 9 de setembro de 1875 , APEBa, Polícia, Casa de Prisão, maço 3087. 
oficina, portanto esse não era o atrativo. Talvez Polibio quisesse acumular cargos. Dois meses depois, lá estava Polibio com uma nova petição ao presidente da província. Dessa vez ele foi atendido ao solicitar verba e licença remunerada de um mês para expor sua "invenção" na Corte Imperial na exposição de 2 de dezembro de 1875. Tratava-se do móvel "multiforme" desenvolvido na oficina da CPCT e, por isso, "propriedade da mesma". ${ }^{117}$ O sucesso do "multiforme" está também registrado no trabalho de Silvia Cunha sobre as exposições no século XIX. Segundo a autora, em 1876 Polibio participou da exposição internacional da Filadélfia, sendo premiado juntamente com outros 22 representantes da província da Bahia. Em 1878, teria ele recebido a medalha de mérito na exposição nacional do Rio de Janeiro. ${ }^{118}$ Infelizmente, não encontrei uma descrição do móvel "multiforme". O historiador Aldrin Castelucci nos traz mais informações sobre Polibio para o ano de 1890, quando este compunha a chapa do Partido Operário da Bahia, ao lado do pintor, desenhista, abolicionista e pesquisador Manoel Querino, entre outros. ${ }^{119}$ Pelo que sabemos de Polibio, dá para imaginar que ele foi uma pessoa atuante no processo de formação da classe trabalhadora baiana, assim como os que viviam ao seu redor.

As oficinas estiveram em atividade durante todo o século XIX, e também no XX. ${ }^{120}$ Em 1884, o administrador informaria em seu relatório que as oficinas em funcionamento eram as de sapateiro, encadernação, charuteiro e marceneiro. ${ }^{121}$ Com exceção da oficina de marceneiros, o funcionamento das demais oscilaram a depender da demanda e dos investimentos do governo para, finalmente, se

117 José Polybio da Rocha para o presidente da província, 2 de novembro de 1875 , APEBa, Polícia, Casa de Prisão, maço 3087.

118 Cinthia da Silva Cunha, "As exposições provinciais do império: a Bahia e as exposições universais, 1866-1888" (Dissertação de Mestrado em História, Universidade Federal da Bahia, 2010), p. 100.

119 Aldrin A. S. Castelucci, “Trabalhadores, máquina, política e eleições na Primeira República” (Tese de Doutorado em História, Universidade Federal da Bahia, 2008), p. 65,113.

120 Para o século XX, ver, por exemplo, "A penitenciária” in Revista do Brasil, Bahia, 31 de março de 1908, ano II, n.13, pp. 3-20. Para o ano de 1930, ver Manoel Rodriguez Folgueira (org.), Album Artístico, Comercial e Cultural do Estado da Bahia, Salvador, Edições Folgueira, 1930, pp. 89-97.

121 Administrador Valentim Antonio da Rocha Bittencourt para o chefe de polícia, 1 de março de 1884, APEBa. 
estabilizarem no final do século. Um novo regulamento, elaborado em 1880 e não implantado pelo menos até 1890, revela a preocupação das autoridades em ampliar e reorganizá-las, prevendo a seguinte disposição: "de marceneiros, compreendendo carapinas, carreteiros, torneiros e tanoeiros. De ferreiros, compreendendo caldeiros, funileiros, lampistas e maquinistas. De encadernadores com um pequeno prelo para impressão de livros. De sapateiros, alfaiates e charuteiros, compreendendo cigarreiros". ${ }^{122}$ Não tenho notícia se esse planejamento foi colocado em prática posteriormente.

Contrariando o discurso dos reformadores, o trabalho nas oficinas da CPCT não era obrigatório como previa o regulamento. Mesmo que fosse, elas não comportariam todos os sentenciados. A oficina tornou-se um lugar cobiçado entre os presos. Além da remuneração, ali encontravam a possibilidade de lucrar com outros "negócios". No ano de 1885 as oficinas de sapateiro, encadernador e, charuteiro e marceneiro renderam aos cofres da prisão 1:625\$027, resultado da diferença entre a receita de 5:403\$893 e a despesa de 3:778 $\$ 776$. No ano seguinte, juntou-se a elas a oficina de fabrico de caixa de fósforos. ${ }^{123}$

\section{Sobre os presos}

O perfil dos presos da CPCT não sofreu alteração durante o século XIX. Na sua maioria eram homens, pardos e crioulos, sentenciados por crime de morte ou de furto, este último em menor número. ${ }^{124}$ A penitenciária da Bahia não tinha calabouços nem celas para escravos, como acontecia, por exemplo, no Rio de Janeiro e São Paulo. O número reduzido de escravos e libertos que se encontravam

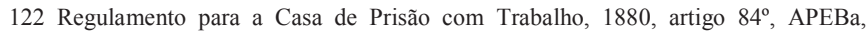
Polícia, Mapa de Presos, maço 6278.

123 Fala com que o Excelentíssimo senhor Conselheiro Theodoro Machado Freire Pereira da Silva, abriu a $26^{\text {a }}$ legislatura da Assembleia Legislativa Provincial no dia 3 de abril de 1886, Bahia, Typographia da Gazeta da Bahia, 1886, p. 43.

124 Diversas guias de presos, APEBa, Polícia, Casa de Prisão,1861-1864, maço 5942. 
na CPCT era, geralmente, de sentenciados à pena da morte que aguardavam a graça do imperador. Aos libertos a lei permitia aplicar a pena de prisão com trabalho, mas eles tinham pouca representatividade, ficando subentendida a preferência das autoridades em reabilitar homens livres. No período de 1861 a 1868 , localizei cerca de dezesseis mulheres na CPCT, mas as autoridades logo trataram de transferi-las para a Casa de Correção, onde não existia projeto penitenciário. As autoridades alegavam dificuldades na separação de homens e mulheres por conta de obras não finalizadas. Se de fato a penitenciária baiana proporcionou melhores condições prisionais, além da oportunidade de futura ressocialização, as sentenciadas foram privadas desse benefício no século XIX. ${ }^{125}$ Nos debates sobre a implantação da CPCT não localizei referência sobre qualquer tratamento diferenciado para mulheres. Essa postura não ocorreu somente na Bahia. Segundo Lucia Zender, por volta de 1853, os regulamentos das prisões femininas de Londres eram os mesmos aplicados às prisões para homens. Os Estados Unidos, país que foi referência na implantação dos sistemas penitenciários no século XIX, construiu sua primeira prisão para mulheres em 1835, em Nova York. Essa prisão, chamada Mount Pleasant Female Prison, foi a única instituição prisional feminina dos Estados Unidos até $1870 .{ }^{126}$ Quanto

125 No período de 1865 a 1868 , há divergências na documentação sobre a data exata em que a penitenciária deixou, definitivamente, de receber mulheres. Enquanto a correspondência do administrador Carlos Silva para o chefe de polícia indica a transferência das mulheres para a Cadeia de Correção no ano de 1865, o relatório do chefe de polícia Franklin Américo de Menezes indica a presença de 22 presas doentes na CPCT no ano de 1868. Em 1869, o presidente da província, barão de São Lourenço, finalmente confirmou que as mulheres deixaram de ser aceitas na CPCT. Administrador interino Carlos Silva para o chefe de polícia, 20 de setembro de 1865 , APEBa, Polícia, Mapa de Presos, maço 6273; "Relatório do chefe de polícia Flanklin Americo de Menezes Doria”, p.2; Relatório apresentado a Assembleia Legislativa da Bahia pelo Excelentíssimo senhor Barão de São Lourenço em 11 de março de 1869, $1^{\mathrm{a}}$ parte, Bahia, Typographia Constitucional, 1869, p.19.

126 Lucia Zedner aborda as diversas formas de exploração das mulheres dentro das prisões, inclusive a sexual, seja por parte dos funcionários ou dos presos. Zedner, "Wayward Sisters", p. 302. Ver também María Soledad Zárate Campos, "Vicious Women, Virtuous Women: The Female Delinquent and the Santiago de Chile Correctional House, 1860-1900", in Salvatore e Aguirre, The Birth of the Penitentiary, pp. 78-100. 
à penitenciária da Bahia, após 1868, ela se transformou numa instituição exclusivamente masculina. ${ }^{127}$

A CPCT atendia toda a província da Bahia, recebendo presos de várias localidades. Para dar uma ideia dessa representatividade provincial, em setembro de 1872 , havia 233 presos procedentes de cinquenta localidades da província.

Conforme consta no censo de 1872, a população da província era de 1.379.316, e desses, 719.447 do sexo masculino. Em Salvador, dos 129.109 habitantes, 68.020 eram homens, representando 9,4\% da população masculina da província, taxa apenas um pouco abaixo dos $10,3 \%$ dos presos oriundos da capital. A princípio podemos dizer que na relação capital/interior, em 1872, os presos da CPCT tinham uma representatividade equilibrada em relação à população masculina da província da Bahia. O censo de 1872 não contempla todas as localidades citadas na relação de presos, da mesma forma que não separa a população adulta da infantil, o que impossibilita chegar a números exatos. Entretanto, foi possível elaborar uma amostragem que aponta para uma representatividade equilibrada de presos também por regiões da província baiana, com exceção das localidades do litoral norte e do sertão de baixo, que apresentam um índice menor de criminosos na sua população masculina.

Desde a inauguração, em 1861, até o final da década de 1880 a penitenciária manteve equilibrada sua lotação com dois presos em cada cela, na maioria dos casos. Existiam presos que ocupavam uma única cela, como foi o caso de Francisco Ribeiro de Seixas. Na década de 1880, com o aumento da população carcerária, os presos passaram a ser acomodados em número de três na mesma cela, o que seria motivo de críticas nos relatórios dos chefes de polícia e presidentes de província. Nas décadas de 1860 e 1870, a média da população carcerária da CPCT foi de 180 e 200 presos, respectivamente, e ao longo dos anos de 1880 a média foi de 350

127 A Bahia inaugurou sua primeira unidade prisional feminina em 1990 localizada no atual Complexo Penitenciário da Mata Escura. Em 2005 foi transformada em Conjunto Penal Feminino abrangendo além do regime provisório, o semiaberto o aberto e o fechado. 
presos. $^{128} \mathrm{O}$ controle da lotação demonstra a preocupação das autoridades em preservar a filosofia penitenciária da instituição, mesmo com todos os problemas de ordem administrativa e de infraestrutura. Entre eles estavam o terreno pantanoso, sanado no final da década 1880, a falta de materiais básicos, como roupa de cama, uniforme para os detentos, falta de livros para a escola etc. Apesar de tudo, a penitenciária era um orgulho para as autoridades, pois ela fazia com que a Bahia parecesse moderna, e sobretudo por representar um aparato mais efetivo - e, de novo, mais moderno - de controle das "classes perigosas" que ameaçavam a ordem na província. Isso vale para toda a América Latina. Para Carlos Aguirre, "o que atraiu as autoridades latino-americanas para os modelos penitenciários não foi a promessa de reformar criminosos através de meios humanitários, mas seu objetivo muito mais palpável: a possibilidade de fortalecer os mecanismos existentes de controle e confinamento". ${ }^{129}$

$\mathrm{Na}$ outra ponta do complexo prisional de Salvador estava a Cadeia da Correção onde não existia projeto de recuperação, escola, enfermaria, oratório nem celas privativas. Essa cadeia deveria servir apenas como detenção provisória, mas abrigava também sentenciados que não eram mandados para a penitenciária por falta de vagas ou por não serem selecionados para tal pelas autoridades, como por exemplo, os libertos condenados à prisão simples e com trabalho. A exclusão dos libertos na CPCT pode sinalizar um preconceito de condição, vez que quanto à cor os sentenciados da penitenciária eram pardos ou pretos. Provavelmente também um preconceito antiafricano, pois a maioria dos libertos era nascida na África. E preconceito não apenas por parte das autoridades, mas também dos próprios presos. Aquelas podem ter considerado que juntar africanos com nacionais seria uma fórmula para a quebra da paz na penitenciária.

128 A média foi calculada a partir do número de presos existentes no último mês de cada ano do período de 1861 a 1889 . Os dados foram coletados dos relatórios dos presidentes de província.

129 Aguirre, "Prisons and Prisoners in Modernising Latin America (1800-1940)", p. 22. 


\section{Cadeia da Correção}

Casa de Correção, Cadeia da Correção ou, simplesmente, Correção, sendo estas duas últimas denominações as mais utilizadas nos documentos. ${ }^{130}$ A Bahia foi a única província do Império do Brasil a chamar uma cadeia comum de Casa de Correção. De um modo geral, no Brasil oitocentista, essa nomenclatura era empregada para denominar as primeiras penitenciárias, a exemplo da Corte e de São Paulo. Somente na Bahia, a penitenciária recebeu o nome de Casa de Prisão com Trabalho. O que aqui tínhamos como Correção era no Rio chamada de Casa de Detenção e em São Paulo de Cadeia Pública. ${ }^{131}$

A cadeia baiana recebeu o nome de Casa de Correção porque, em 1829, pensava-se em transformar a fortaleza de Santo Antônio numa penitenciária, numa Casa de Correção propriamente, mas o plano não vingou. Naquele ano de 1829 uma comissão da Câmara Municipal constatou que o local não estava destinado a nenhuma "utilidade pública". Foi aí que a comissão sugeriu que fosse adaptada para servir interinamente como Casa de Correção, ou seja, como penitenciária. ${ }^{132} \mathrm{O}$ projeto foi aceito pelos vereadores e, a partir de 1832, teve início o funcionamento daquela que viria a ser a cadeia mais movimentada da província da Bahia na segunda metade do século XIX. O objetivo inicial da Câmara era mandar para lá os sentenciados a prisão com trabalho e, assim, atender ao Código Criminal de 1830 até que fosse construída uma penitenciária de verdade na província. Porém, a Casa de Correção funcionou apenas como cadeia comum desde o início de suas atividades, daí a apenas "Correção".

130 Com base na documentação utilizarei a denominação de "Cadeia de Correção" ou

131 Sobre a Cadeia Pública de São Paulo, ver Araújo Gonçalves, "Cadeia e Correção". Sobre a Casa de Detenção do Rio de Janeiro Amy Chazkel, "Uma perigosíssima lição: a Casa de Detenção do Rio de Janeiro na Primeira República”, in Clarissa Nunes Maia et alli., História das Prisões no Brasil, vol. II (Rio de Janeiro, Rocco, 2009), pp. 111-153.

132 Atas e mais objetos da comissão de visita das prisões civis e militares, 1829, AMS; Sessão de 16 de setembro de 1833, AMS, Atas da Camara, 1833-1835. 
denominação também de Cadeia da Correção, como consta na documentação. ${ }^{133}$

O perfil dos presos da Correção muda consideravelmente em relação ao da penitenciária, pois além dos sentenciados que cumpriam pena por falta de vagas na penitenciária, encontrava-se ali uma população carcerária flutuante e diversificada: homens e mulheres de condição escrava, liberta e livre, crioulos, africanos e europeus. Este último grupo, em menor número, era representado principalmente por portugueses e ingleses. As infrações rotineiras que, geralmente, resultavam em alguns dias de prisão eram brigas, pequenos furtos, embriaguez, batuque ou candomblé, desordem, infração de posturas municipais, entre outras, inclusive fuga de escravo. A Correção, e as cadeias comuns de um modo geral, era também o destino dos escravos mandados pelos senhores a fim de serem castigados e, logo depois, devolvidos mediante o pagamento de uma taxa. Mal comparadas, essa cadeia equivale às nossas atuais delegacias.

A CPCT e a Cadeia de Correção, instituições distintas, tanto no perfil de presos quanto nos meios e objetivos punitivos, mais se completavam do que se contrapunham na tentativa de atender às necessidades de uma sociedade escravista rumo ao trabalho livre, como era aquela. Esperava-se da CPCT a garantia do avanço civilizatório da província com seu projeto de reabilitação do criminoso através dos modelos penitenciários. À Casa de Correção cabia o papel de continuar a reproduzir práticas de punição e aprisionamento que não cabiam no projeto de reforma prisional.

De sua inauguração, em 1832, até 1864, a Correção dividiu suas funções com outras cadeias (Tabela 1) até se tornar a única cadeia de Salvador, dividindo o complexo prisional de Salvador com a CPCT. Nessa época, a maioria, senão todas as pessoas detidas nas ruas da cidade eram para ali levadas, o que a transformaria na cadeia de maior rotatividade da província. Para termos uma ideia da movimentação de presos, durante o ano de 1859, quando a Correção

133 Com a reforma prisional no século XIX, os termos prisão e cadeia tomaram conotações diferentes. A prisão seria o local para onde eram mandados os presos sentenciados, e a cadeia abrigava aqueles que aguardavam julgamento ou estavam detidos por pequenas infrações. 
coexistia com as cadeias do Aljube e do Barbalho, seu movimento de entrada e saída foi de 792 presos. Já no ano de 1868, quando só existia ela, além da penitenciária, o movimento chegou a 1705 presos. Diferente da CPCT, que manteve o equilíbrio no número de presos durante três décadas, a Cadeia da Correção apresentou um número sempre crescente de presos, acompanhando o aumento da população e, obviamente, oferecendo suporte para evitar que a penitenciária ultrapassasse sua lotação máxima.

A partir do ano de 1868, a prisão dos galés do Arsenal da Marinha ficou proibida de receber mais de trinta presos e, por isso, eles foram transferidos. Alguns seguiram para a ilha de Fernando de Noronha, outros para a CPCT, que passou a recebê-los regularmente, ocasionando sérios problemas, pois a penitenciária não fora preparada para administrar esse tipo de sentenciado.

\section{Cadeias da província}

No período de 1865 até o final de década de 1880 , o número de cadeias da província da Bahia girou em torno de sessenta a 64. Na capital só havia duas. O restante ficava em diversas outras localidades, instaladas em "edifícios velhos e arruinados, nos pavimentos térreos das câmaras municipais, ou finalmente em casas alugadas a particulares". ${ }^{134}$ Os documentos policiais e os relatórios de presidentes da província descrevem as péssimas condições dessas cadeias, destacando as questões higiênicas e a total falta de segurança. Essa última era responsável pela recorrente remoção de presos para a capital, mesmo nos casos desobrigados pelo Código Criminal, ou seja, até seis meses de prisão simples o réu deveria cumprir sua pena em qualquer cadeia próxima à sua residência. ${ }^{135}$ Esses traslados

134 Anexos à fala com que o desembargador Henrique Pereira de Lucena, presidente da Bahia, abriu a 56 ${ }^{\mathrm{a}}$ legislatura da Assembleia Legislativa Provincial no dia $1^{\circ}$ de março de 1877 , p. 11.

135 Filgueiras Junior, Código Criminal do Império do Brasil Anotado, Artigo 48, p. 36. 
facilitavam fugas e oneravam os cofres públicos, principalmente por conta da escolta policial.

Pelo menos até o final do século XIX, o que as autoridades baianas entendiam por aprisionamento moderno só estava sendo aplicado na penitenciária. A Cadeia da Correção, em Salvador, e as dezenas de cadeias espalhadas pela província ainda respiravam ares coloniais. A maioria dos presos estiveram numa dessas cadeias antes de serem mandado para a penitenciária fazendo com que suas experiências anteriores a entrada na penitenciária contribuísse no processo de construção do cotidiano prisional da nova instituição.

RECEBIDO EM: 15/05/2016 APROVADO EM: 20/06/2016 